\title{
Asymmetries in Housing and Financial Market Institutions and EMU*
}

\author{
Duncan Maclennan $^{1}$, John Muellbauer ${ }^{2}$ and Mark Stephens ${ }^{3}$
}

July 2000

\begin{abstract}
Despite convergence pressures, differences in housing and financial market institutions across the 15 member states of the European Union are still enormous. This paper argues that they have profound effects on the responsiveness of output and inflation in the different countries to changes in short-term interest rates, as well as to asset market shocks of external origin. The economic reasoning behind this claim is set out and the institutional differences are described. The paper assesses the sometimes conflicting empirical evidence on this issue. Barriers to convergence and implications for labour market flexibility are discussed. The UK, Ireland, Finland and Sweden tend to cluster at one extreme of the relevant institutional characteristics. The paper includes a set of proposals for institutional reforms to reduce the tensions within EMU and the potential for instability in these economies entailed by EMU membership. The paper connects the symptoms of overheating in the Eurozone observed in mid-2000 with our analysis and concludes by reviewing prospects for the UK.
\end{abstract}

This is an updating of the paper with the same title published in the Oxford Review of Economic Policy, 14:3, Autumn 1998. We are grateful to Janine Aron, Gavin Cameron, David Hendry, Diana Kasparova, Bertrand Renaud and participants at a Bank of England seminar, particularly Maxwell Fry and John Vickers, for helpful comments. We thank the following for providing information: Nicole de Windt (European Mortgage Federation), Yvonne Galligan (The Policy Institute, Trinity College, Dublin), Marietta Haffner (OTB, Delft Technical University), Anne Laferre (INSEE, Paris), Sirpa Tulla (Ministry of Finance, Helsinki). John Muellbauer is grateful for research support to the ESRC under grant number R000237500.

$1 \quad$ Mactaggart Professor, Department of Urban Studies, Glasgow.

2 Official Fellow and Professor of Economics, Nuffield College, Oxford.

3 Senior Lecturer in European Housing, Department of Urban Studies, Glasgow. 


\section{Introduction}

When the European single currency was launched on 1st January 1999, only the UK, Sweden, Denmark and Greece of the 15 members of the European Union did not join. Greece is to join in January 2001, and a referendum on membership is to be held in Denmark. The national currencies in the new Eurozone are locked together irrevocably as mere denominations of the Euro, although domestic notes and coins will not be phased out until the first half of 2002. Interest and exchange rate policies are managed by the independent European Central Bank (ECB) whose primary objective, as established by the Maastricht Treaty, is 'to maintain price stability'. In the run up to monetary union, its prospective members were under pressure to meet qualifying convergence criteria which contributed to major shifts in fiscal policy across Europe. These entailed a much greater concern with government deficits and debt. Fiscal policy is now subject to the Growth and Stability Pact, under which, other than in exceptional circumstances, government deficits will be limited to 3 per cent of gross domestic product, implying a further structural tightening of fiscal policies. The fiscal regime established by the convergence criteria and the Growth and Stability Pact seem certain to add to the pressures arising from the ageing of the west European population which encourage the reform of pension policies away from pay-as-you go towards funded systems.

The link between the European internal market and the single currency has been receiving increasing emphasis. The Maastricht and Amsterdam treaties created a framework for establishing minimum standards of conduct in social policy. The December 1997 agreement by EU finance ministers on a non-binding code of conduct to tackle "unfair" tax competition has been followed by further peer pressure towards a degree of tax harmonization, for example, on households' investment incomes.

For companies there have been profound consequences. With intra EMU exchange rate risk eliminated, transactions cost and cash management cost have fallen. The whole spectrum of interest rates has tended to converge towards the low rates of the core. The European corporate bond market has become deeper and more attractive to companies. Equity markets too have become deeper as companies obtain a greater proportion of finance from equities (see, for example, the German 'Neuer Markt') and bonds and a reduced proportion from banks, and as the funded pension sector expands, McCauley and White (1997). Partly as a result, there has been a pronounced increase in corporate mergers and 
acquisitions. The banking sector is likely to undergo further consolidation both as a result of these pressures and because of increased competition, White (1998). The consequences for Europe's relatively inflexible, highly regulated and often heavily taxed labour markets are likely to take longer to work through. However, the major reduction in unemployment in Spain is evidence for the powerful potential effect of the combination of improved demand conditions and labour market deregulation.

With considerable ongoing structural change in the EMU countries and the other changes already discussed, as well as in policy feedback rules themselves, the Lucas critique suggests that the ECB will not have an easy task. Moreover, as we shall argue, a common interest policy will have a different impact in different countries.

At the macroeconomic level, there have been serious attempts to study differences in the monetary policy transmission mechanisms between European countries. The evidence based on 'large' econometric models developed by national central banks linked to the Federal Reserve's multi-country model, see BIS (1995), suggests that of the countries studied (Germany, Austria, UK, Spain, France, Netherlands, Belgium and Italy), the UK had by far the greatest sensitivity of output to interest-rate rises. ${ }^{4}$ Moreover, because variable rate mortgage costs have a large weight in household budgets, as well as in the Index of Retail Prices, the UK is unique in having a positive response of inflation to a rise in interest rates both in the year of the rise, and in the following year, before turning negative in the third year.

However, vector autoregression (VAR) models tend to show much less conclusive differences amongst countries, see Gerlach and Smets (1995), Barran et al (1997), Britton and Whitley (1997). ${ }^{5}$ This evidence appears to have made many economists sceptical of the view that there are important differences. Two of our aims in this paper are to identify important institutional differences which exist in asset markets, and particularly those in housing and credit institutions, and to demonstrate that these differences necessarily imply large differences in the monetary transmission mechanisms across European countries. Moreover,

The response was more than double that in Germany, France and Italy, whose responses were quite similar, and, in turn, bigger than those of the Netherlands, Belgium and Spain. The Fed's own multicountry MCM model also shows the UK with the biggest output response, but that of Italy smaller than the similar German and French responses.

5 However, Dornbusch et al (1998), using a modified VAR approach claim that, in the 1985-95 period, Italy had a larger output response than Germany, France, Spain and the UK. 
institutional differences, not only in asset, housing and credit markets, but in the associated legal, regulatory and fiscal structures, creates barriers for the degree and speed of convergence one might expect under EMU.

Economists are well aware that asymmetric shocks or asymmetric responses to common shocks could pose serious strains on a monetary union. However, the examination of asymmetric responses has tended to focus on differences in labour and capital market characteristics, in relative openness to international trade, and in industrial structure (e.g. the share of capital goods or construction in output).

This emphasis reflects the concerns of mainstream economic models of exchange rate flexibility and optimal currency areas. These models have important points to make, but invariably disregard the role of factors of production, consumption facilities or assets which have a fixed spatial location (most obviously land, property and housing). For instance, in their otherwise excellent summaries of optimal currency areas, De Grauwe (1995) and Eichengreen (1994) discuss adjustment processes almost exclusively in relation to labour markets. Krugman (1992) may have encouraged 'international' economists to become 'regional' economists, but even his analysis does not consider how markets for spatially-fixed factors operate.

Housing markets and systems are major sectors of advanced economies. In Europe, paying for housing typically involves a fifth to a quarter of disposable incomes, while housing wealth is the chief form of wealth for many households. Residential investment usually comprises around a fifth of Gross Domestic Capital Formation. The construction sector provides five to ten percent of all European employment. Housing-related expenditures, except in the Mediterranean area, typically comprise five to ten percent of public expenditure (or one to four percent of GDP), and this share was much higher in the past. Moreover, housing systems have important repercussions for labour mobility, and hence the efficient functioning of labour markets. Our paper also discusses this microeconomic dimension, or the supply side.

The last issue with which our paper deals concerns policy. Having identified large differences across Europe in institutions and histories concerning asset, housing and credit markets, we argue that potentially there are changes in fiscal, regulatory and legal structures which could ameliorate the divergent pressures which asymmetric shocks and asymmetric responses to common shocks and short-term interest rate movements pose for countries.

The structure of the paper is as follows: Section 2 offers a non-technical theoretical summary of the impact of raising the short-term interest rate on the components of GDP, 
namely consumption, investment, net exports and government expenditure, as well as the impact on inflation. In both cases, careful attention is focussed on the implications of differences in financial institutions and history for these monetary transmission mechanisms. In our view, there is currently insufficient awareness amongst both economists and policymakers of the crucial role played by these differences.

Section 3 provides evidence on institutional differences across Europe in asset, housing and credit-markets. A connection is made between these institutional differences and econometric evidence on the interest-rate-to-output linkages and other features of macroeconomic behaviour. Furthermore, the likely impact of these differences in generating asymmetric reactions to outside shocks is analysed.

Section 4 discusses the implications of the earlier analysis for the process of convergence in the EMU economies. Supply side issues, particularly those stemming from housing and labour market interconnections, are then considered in Section 5.

We conclude with a summary in Section 6. We discuss which fiscal, regulatory and legal changes might ease the tensions EMU membership is likely to create, particularly for the more divergent economies, such as the UK, Ireland, Finland and Sweden. We also show that the analysis of this paper has considerable predictive power in explaining where overheating problems in the Eurozone have occurred in the 20 months since the original version of our paper went to press. We conclude by examining whether the UK has made progress to sustainable entry.

\section{Institutional Differences and the Monetary Transmission Mechanism}

The theoretical background of this section broadly takes an income-expenditure approach to the determination of output. Thus, total expenditure is given by

$$
\mathrm{C}+\mathrm{I}+\mathrm{X}-\mathrm{M}+\mathrm{G}
$$

where $\mathrm{C}$ is consumer spending, $\mathrm{I}$ is gross investment spending, $\mathrm{X}$ is export receipts, $\mathrm{M}$ is spending on imports and $\mathrm{G}$ is government spending. Goods markets are in short-run equilibrium when total expenditure, given current output, equals current output. Economists assume a short-term adjustment process bringing expenditure and output into balance, for given asset prices, interest rates and income expectations. 
There are also longer-term adjustment mechanisms bringing total expenditure or output into line with the evolving capacity of the economy ${ }^{6}$ to produce. These mechanisms involve, for instance, wage and price adjustment, fluctuations in unemployment and asset price changes, including exchange rate changes. Since capacity (the supply side) evolves slowly, the burden of adjustment is mainly borne by the expenditure or output side. Macropolicy feedback rules generally aid the process of adjustment: interest rates rise when output growth threatens to exceed capacity growth and raise inflation, while the reverse occurs when output growth is weak. ${ }^{7}$ Taylor(1995) gives a useful integrated account of a simple version of the monetary policy transmission mechanism and the role of monetary policy feedback rules.

It is far from clear that asset prices play a stabilizing role in this adjustment process in the absence of interest rate changes. For instance, it is possible for the extra profits created in an output expansion, particularly when labour power is subdued, to create large enough increases in asset values to fuel an endogenous process of credit creation. Then, the rise in interest rates resulting just from the greater credit demand may be insufficient to subdue the expansion. This seems to have been an important element in the 'bubble economy' period in Japan, in the UK and most of Scandinavia in the late 1980s and in the US in 1997-8. Indeed, it is likely that the Basle agreements on capital adequacy ratios of banks assist in institutionalizing this endogenous process of credit creation. The asset prices of banks tend to rise in business cycle upswings, expand the capital base and thereby stimulate credit creation. In downswings, the process tends to go into reverse, leading to less credit becoming available just when businesses need credit to carry them through temporary difficulties.

Below we explore the monetary transmission mechanisms by considering the effect of a rise in the short-term interest rate in different sectors. Many, but not all, of these effects would be articulated in the current large econometric models.

\subsection{Consumer Expenditure}

The capacity to produce in turn depends on the labour force and its quality, the result of past decisions on education and training, the size of capital stock, the stock of R\&D, and also on the public infrastructure. The quality of these stocks depends, inter alia, on technological innovation and imported technology, the efficiency of capital markets in guiding investment decisions and public sector efficiency. In the long-run, capacity is thus endogenous, responding to past expenditure and other decisions. 
This is the single most important sector, accounting typically for 55-75 percent of GDP. Research suggests that there are both direct and indirect effects of interest rates on consumer spending. ${ }^{8} \quad$ There are three indirect effects of interest rates on consumer spending: on expected income growth, on income uncertainty or volatility, and on asset prices. Together, these appear to be quantitatively more important than the direct effects.

\section{Direct Effects}

The real interest rate is generally believed to act most strongly on the consumer durables component of consumer expenditure, via user cost. ${ }^{9}$ In general, for consumption, the economic theory of income and substitution effects, see Appendix 1 for a simple exposition, suggests that, in the absence of credit rationing, the direct real interest rate effect depends on three factors: the greater is the degree of intertemporal substitutability of preferences, the lower are asset to income ratios and the greater is expected growth of future income, the more negative will be the direct effect of a rise in the real interest rate, holding asset values and income expectations constant. However, the empirical evidence suggests this effect is often quantitatively small. A positive effect is theoretically possible and there has been empirical controversy on the sign of the effect in different countries, see Deaton (1992, section 2.2). Where the interest on consumer credit is a floating rate linked to short-term rates, there can also be a negative effect on consumer spending from an interest rate rise, as cash flows of indebted consumers fall. Such effects will be weaker where additional finance is readily available. There are large cross-country differences in the proportion of consumer debt at floating rates. There are also cross-country differences in whether tax relief is given for interest on debt. This means that a given percentage point rise in the interest rate on debt has different after-tax effects in different countries.

$7 \quad$ That is, unless the inflation inherited from the past is too severe for policy-makers to cut interest rates.

8 See, for example, the UK models surveyed in Church et al (1994) and Barrell et al (1991) for multicountry models. Theory background is given in Muellbauer and Lattimore (1995); Muellbauer and Murphy (1995, 1997) articulate the separate channels more distinctly. Borio (1997) has an illuminating discussion of differences in credit market structures on interest rate transmission effects.

9 "User cost" is defined as the rate of physical depreciation, plus the nominal interest rate, less the expected rate of price appreciation of the good, all multiplied by the price of the durable good. 


\section{Indirect Effect Via Expected Income Growth}

The channel which operates via expected income growth can be investigated by estimating reduced-form income forecasting models, allowing for appropriate parameter shifts induced by shifts in policy feedback rules, see Muellbauer (1996). The real exchange rate and real domestic asset prices, which respond to interest rates, usually have predictive power in such models, even after controlling for short-term interest rates. The fitted values from such a forecasting equation typically have significant effects in consumption functions, even after controlling for direct interest rate effects and asset effects. Moreover, economic theory predicts that in a financial system with deregulated credit markets, intertemporal trade-offs and hence the role of income growth expectations are more important.

\section{Indirect Effect via Income Uncertainty}

Income uncertainty can plausibly be proxied in empirical models by changes in the unemployment rate: this captures well the sensitivity of consumers to the probability of job losses. The unemployment rate tends to respond with a lag to rises in short-term interest rates, thus capturing part of the dynamic response of consumption.

\section{Indirect Effects Via Prices of Financial Assets}

Finally, perhaps the most powerful effects of a rise in short-term interest rates on consumption operate via asset prices. For government bonds, the effect is to cause prices of bonds to fall, operating via the term structure of interest rates. ${ }^{10}$ For corporate bonds, there is an additional negative effect due to the reduction in expected growth, which increases corporate default probabilities. For equities, prospective returns fall via reduced expected growth, lower after-interest cash flows (depending on how sensitive corporate loan rates are to short-term interest rates and on debt to earnings ratios, both of which vary across countries), increased bankruptcy probabilities and the heavier discounting of future returns. Note that differences between countries in the sensitivity of growth to short-term interest rates will enhance the differences in asset price responses to interest rates. The consumption response to interest rates via asset prices depends both on asset to income ratios and the 
perceived liquidity or spendability of these assets (see below). There are variations in both these elements across countries. Countries with the most comprehensive pay-as-you-go pension systems will have the least developed pension funds and are likely to have lower asset to income ratios. Since pension funds are less liquid than directly-held securities the indirect consumption response to interest rates will also depend on the portfolio composition of securities between pension funds and directly held assets.

There is another aspect of this channel traditionally emphasized by monetary economists. The rise in interest rates should cause a portfolio switch by consumers into less liquid and so less spendable assets: away from non-interest bearing bank deposits to interest bearing deposits and out of liquid assets in general into cheaper bonds and equities. The shrinkage in bank deposits should cause a reduction in the credit advances of the banks. The magnitude and timing of these portfolio-switching effects is debatable. This is because the rise in interest rates may cause consumers to become more cautious, save more in liquid form, and, for a time, hold off from buying bonds and equities in case their prices should fall further.

\section{Indirect Effects via House Prices}

In many European countries housing wealth accounts for over half of household net wealth. In principle, one might expect substantial interest rate effects on consumer expenditure via housing wealth. However, of all components of the monetary transmission process, institutional differences between countries are likely to bite most deeply here, implying large effects in some countries and tiny ones in others.

Simple life-cycle consumer theory suggests that a rise in real house prices believed to be long-lasting has both a positive wealth effect on non-housing consumption, and negative income and substitution effects, see Appendix 2 for a simple exposition. Plausible estimates of the latter effects, in UK and other studies, e.g. Meen (1993), suggest elasticities in the region of -0.5. The positive wealth effect will therefore dominate for owner-occupiers. However, for tenants in the market rented sector, the effect is unambiguously negative. The intuition for this is that those continuing to rent can expect higher future rents when house prices rise, while those aiming to purchase a house have to save more for a deposit and can expect to have higher total costs. However, we also have to consider the wealth effect for landlords or the institutional investors owning rental housing. If these wealth effects are smaller per unit of wealth than for owner-occupiers, (e.g. because of liquidity considerations discussed below), then, other things being equal, the higher the proportion of owner- 
occupiers and the lower the proportion of households in the market rented sector, the larger will be the consumption response to a rise in house prices. As we shall see in Section 3, there are large variations in these characteristics across Europe.

The simple life-cycle model does not capture the whole story. The other major crossEurope variation concerns the perceived liquidity or spendability of housing assets. The key liquidity characteristics are defined by transactions costs and restrictions, asset price volatility and the collateral role of the asset. Transactions costs include costs of (real) estate agents and lawyers and taxes, such as stamp duty. If housing is particularly sheltered from inheritance taxes, this can, in effect, translate into a restriction on resale. Since consumers are particularly averse to capital loses and to the negative consequences of loan default, one might also expect an asymmetric response to house price volatility (i.e. a history of recent falls is likely to reduce the spendability of housing wealth).

The third aspect of liquidity, the collateral role of housing wealth, is of crucial importance and subject to enormous variations across Europe. Loan-to-value ratios available to first-time buyers range from around 40 percent to 95 percent. Behind these variations lie differences in credit market institutions, the legal system (how rapidly, if ever, can mortgage lenders possess the property in the case of loan default) and any taxes paid by sellers. Where housing is regarded as excellent collateral, housing is in effect more spendable and house prices will impact much more strongly on consumer spending.

Liquidity considerations also suggest that where pension funds and similar institutional investors own a large fraction of rental housing, the wealth effects on consumer expenditure of higher house prices on rental housing would be smaller per unit than for the owner-occupied sector. The reason is that pensions are a rather illiquid component of consumers' portfolios and so are less spendable.

Finally, abstracting from the very important liquidity issues, we must address the issue of to what degree housing wealth is really part of a nation's wealth, which frequently troubles economists, see Miles (1994), ch 4. The simple life-cycle model in Appendix 2 is a model of individual behaviour. In a closed economy ${ }^{11}$ with a constant population, if many households attempted to translate higher house prices into higher non-housing consumption by liquidating part of their housing wealth (e.g. moving to a smaller house), they would force

11 The upper end of the housing market in London and the South East now has a very considerable element of foreign ownership. Therefore, one should not exaggerate the degree to which economies are 'closed' with respect to housing. 
down house prices in the process. At the individual level, housing wealth looks spendable. A super-rational representative household, aware of the difficulty all households would have in spending a major part of their housing wealth, would take a more jaundiced view. Indeed, it seems likely that if UK households had been collectively more rational in the late 1980s, the consumption boom and its repercussions for the balance of payments and inflation would have been less extreme.

So far, we have discussed only the house price-to-consumer spending linkage. But institutional and historical differences can also impact profoundly on the link between shortterm interest rates and house prices, themselves. This has been shown by Muellbauer and Murphy (1997) studying the relatively speculative and volatile UK market, while Muellbauer (1992) examines the very different German market. In the UK, there appear to be six components in the interest rate-to-house price transmission channel. The first is a negative real interest rate effect, enhanced by the financial deregulation of the 1980s. The second, which is quantitatively particularly important, operates via the rate of return in housing (measured as the rate of capital appreciation plus imputed rent minus a measure of the mortgage cost or alternative return on liquid assets). There is clear evidence both of an important element of extrapolative expectations and of an important non-linearity in the response of households to this rate of return, supporting an earlier finding by Hendry (1984). The non-linearity results from transactions costs: as returns rise, the transactions cost hurdle becomes less and less relevant, and both transactions volume and the speed of change of prices increases. To put it another way, speculative 'frenzy' tends to set in. The third effect is also non-linear, and operates through a downside risk measure which is zero if the (geared) rate of return in recent years was positive, but equals the average lagged return if this return is negative. Both the fourth effect, operating via income expectations, and the fifth, acting through financial asset prices, have already been discussed above. A sixth effect can also be distinguished, operating through expectations of house price appreciation. ${ }^{12}$ The model naturally also gives the more basic forces of income, demography and the supply of houses their due.

12 The fact that this appears as a separate effect in Muellbauer and Murphy (1997) is due to the semirational expectations model used to define house price expectations. This separate channel would disappear if these expectations had been defined by a mixture of fully rational and crudely extrapolative expectations. 
There are several policy implications from this research. The first is that in speculative markets such as the UK, the dynamics of the response of house prices to interest rates are non-linear and non-constant over time. A standard VAR reduced-form specification could only ever be a poor approximation to this process. For example, given the upward momentum of house price appreciation in 1987-8, the reaction to the interest rate rises in 1988-9 took some time to feed through. But the non-linearities and the downside risk factor contributed to making the subsequent crisis in the housing market deeper and longer than standard models or most observers predicted at the time. A second implication is that history matters. If consumers' experience is of house price changes which are heavily serially correlated, then this will be part of the expectational mechanism which tends to make history repeat itself. A third implication is to stress the importance of transaction costs: high transaction costs reduce the probability of speculative frenzies. Fourth, the prelevance of easy credit availability raises gearing levels, and makes expectations and intertemporal choices more relevant, and hence speculative behaviour more likely. Finally, and perhaps most obviously, the sensitivity of the mortgage interest rates which people actually pay to short-term interest rates is likely to prove a crucial issue. Where most mortgages are at fixed rates for long durations, the short-term interest rate effect on house prices and on to consumption will necessarily be small. As we shall see, in the relevant dimensions there are again large institutional differences across Europe.

Many of these factors help to explain why house prices are more volatile in some countries than others. Price volatility increases with more volatile demand and supply, and lower elasticities. Characteristics favouring high demand volatility are low transactions costs, easy credit availability as reflected in high loan-to-value ratios, thus permitting high levels of gearing, and a high proportion of floating rate mortgages. The market rented sector offers a potential safety-valve which can divert demand from the owner-occupied market when prices are very high. This suggests that countries with small market rented sectors are more likely to have volatile house prices, ceteris paribus.

Countries with bigger feedbacks from house price shocks are likely to experience greater house price volatility: a house price shock, which raises expenditure and therefore income, feeds back on itself, thus amplifying the initial shock. Countries with a less elastic supply of housing should also experience greater house price volatility.

Finally, ceteris paribus, one expects an economy with greater income and inflation volatility also to have more volatile house prices. However, it is at least conceivable that even though an economy has institutions which favour an above average degree of house 
price volatility, if the automatic stabilizers and the monetary and fiscal policy feedback rules were very efficient, income and inflation volatility could be below average, compensating for an innately more volatile housing market.

To summarize, countries with largely pay-as-you-go social security and pension systems, large market rented sector, high transactions costs for housing, restricted consumer credit availability and fixed-rate mortgage markets, are likely to have consumer expenditure largely driven by income and income uncertainty, with relatively weak asset effects and necessarily weak interest rate effects on consumer expenditure. The opposite will be true in countries such as the UK, where the institutional features lie on the opposite extreme of the spectrum.

\subsection{Private Investment Expenditure}

One important component of investment is residential construction, well known to be interest rate sensitive both because of the impact on builders' costs of finance and because of the demand impact, see above. In countries where fixed-rate mortgage finance dominates, if a rise in short-term rates is associated with the expectation of further rises to come (which would raise the cost of future fixed-rate finance), households have an incentive to buy now, in order to lock into currently lower rates. Of course, borrower behaviour will also respond to rules regarding pre-payment. The tendency therefore is for the short-run impact on residential investment of short-term interest rates to be smaller where fixed-rate mortgage finance dominates.

The research on investment of recent years, see the reviews by Bond and Jenkinson (1996) and Schiantarelli (1996), has tended to confirm an older view, well-expounded by Evans (1969), that firms face non-linear costs of finance. Access to equity, and especially to bond markets finance, is restricted to bigger firms. Small firms draw largely on retained earnings, bank finance and hard-to-arrange private loans. Banking systems across countries tend to differ in the role played by collateral, and the degree to which borrowing rates are cushioned from current money market rates. Moreover, the importance of bank, equity and bond finance differs across countries. One therefore expects shifts in interest rate responsiveness over time, depending on whether firms are flush with retained profits or not, and on their liquidity position; and over countries, differences in interest rate responsiveness, depending on the major sources of finance, how equity prices respond to rises in short-term interest rates, and the importance of assets (such as the homes of small entrepreneurs) taken 
as collateral. These mechanisms are part of the "credit channel" through which monetary policy operates, see Bernanke and Gertler (1995). Analogous with consumption, one should expect to find interest rate effects on investment to act through several different mechanisms. These operate via the user cost of capital, via cash flows and liquidity, via growth and the exchange rate (and hence profit expectations), and via asset prices (which affect both equityfinance and the value of collateral). Institutional differences between countries are likely to generate some differences in these responses.

\subsection{Net Trade}

The size of the trade balance (exports minus imports) depends on the real exchange rate, operating with a considerable lag. Also important are domestic and foreign income as well as income growth, domestic and foreign capacity utilization, and perhaps the costs of export finance. Models with such features have been common, though not universal, in large macroeconometric models for 25 years or more. Typically, without capacity utilization effects, income elasticities of imports and exports can be implausibly large. Interest rate changes impact on the trade balance via the real exchange rate, via income growth and via capacity utilization. Under EMU, if there are cross-country differences in the interest rate impact on expenditure growth, due to institutional differences in financial markets, then there will also be differential effects on the trade balance in those countries.

\subsection{Government Expenditure}

Since social security expenditure rises with unemployment, there is therefore an automatic stabilizer which eventually dampens the expenditure effect of the rise in interest rates. Less obviously, particularly in countries with high government debt to income ratios, there is likely to be a negative effect on expenditure via the government's fiscal policy reaction function. The EU's Stability Pact aims to limit government deficits to 3 percent of GDP, except during severe recessions. Belgium and Italy with large stocks of government debt, need to run substantial primary surpluses since the real debt-service costs alone can be 6 or 7 percent of GDP. If there is a large rise in short-term interest rates these debt-service burdens increase and will entail tax rises or government expenditure cuts, in either event impacting negatively on total expenditure and GDP. 


\subsection{Inflation and Short-tem Interest Rates}

Monetarist views of inflation in advanced economies of the European-type have been largely discredited by the empirical evidence. As Hendry (1985) already noted, inverting a money demand function gives a hopelessly unstable model for inflation. Moreover, accumulated evidence from VAR models, see Todd (1990) and Friedman and Kuttner (1992), finds little evidence of a causal link from money to prices, though there is some evidence of a link from short-term interest rates to inflation, Bernanke and Blinder (1992). An eclectic modern view of inflation would focus on 'the output gap' (the deviation between current expenditure or output and the long-run capacity of the economy to produce), on asset prices, on labour market power of workers and on the product market power of imperfectly competitive firms. The asset price universally thought to be relevant for inflation is the exchange rate, which is influenced by short-term interest rates. The other asset price, often neglected, but with important direct effects for inflation in addition to those via the output gap, is the price of housing. House prices enter the cost-of-living index via rents and via the housing costs of owner-occupiers. As Bover et al (1989) and Muellbauer and Murphy (1991) argue, increased speculative asset demand for housing can crowd out workers, and, as in the UK of the late 1980s, and again to some degree now, this can increase regional mismatch if the regions where these speculative demands are greatest are also those where excess demand for labour is the greatest. UK evidence on regional migration, see Jackman and Savouri (1992) and Cameron and Muellbauer (1998), certainly finds large house price effects on migration; while evidence on UK regional wage rates in Blackaby and Manning (1992) confirms the effect of lagged house prices on wages. Once again, economies with low transactions costs in housing, easy credit availability and high proportions of owner-occupation are likely to be the ones most prone to the house price to earnings transmission channel. The implications for the interest rate to inflation link, however, depend crucially on whether mortgage costs are an important element in the cost of living, both in reality and in cost of living indices.

\section{Evidence on Institutional Differences}

We argued in the previous section that differences in housing tenure patterns, housing finance systems and transactions costs in housing have profound consequences for the interest rate transmission mechanism operating via housing. We first examine the facts on European differences for these housing institutions in turn, and then consider differences in some other asset markets and in corporate finance. 


\subsection{Housing Tenure}

The overall tenure structure of the EU breaks down into 56 per cent home-ownership, 21 percent privately-owned renting and 18 percent not-for-profit or social housing. The crosscountry differences in tenure are pronounced (see Table 1), with a North-South divide, and contrasts between the large welfare state system of the Netherlands, the UK and Sweden and other European states with a social democratic heritage, and the rest of the EU.

Simply on the basis of these figures, one might have predicted a large positive impact of housing wealth on consumption in the high owner-occupation and low private rental countries, Spain, Ireland, Italy, UK and Finland. However, the relative size of the private rented sector alone does not tell the whole story. Also relevant is the proportion of dwellings (still) subject to rent control. Sweden and Italy are among those with significant numbers of households still with controlled rents.

\subsection{Housing Finance Systems}

Housing finance lenders within Europe have evolved within national boundaries, and reflect the influence of localised origins and national policies. Thus, different basic systems of housing finance intermediation have evolved in the different countries (see Table 2 and Borio (1997)). Mortgage bank systems raising wholesale funds by selling bonds to institutional investors, with fixed rate mortgages and no significant local branch networks, dominate in Denmark and Germany, but are also important in Sweden, the Netherlands, Austria and Italy. Elsewhere, deposit-taking systems, transforming the short and long-term savings of millions of households into long-term mortgages, evolved with variable rate mortgages and extensive local branch networks. These retail savings institutions dominate housing finance intermediation in the UK, Ireland, France and Spain, and may co-exist with mortgage banks in other countries, for example Germany and Austria. As a sub-set of deposit-taking systems, contractual savings systems for home loans also exist in Germany and Austria, while housing saving schemes exist in France, Spain and Finland.

Variety in basic systems across countries was reinforced, until at least the 1980s, by policy measures to favour housing finance within national capital markets, creating "special circuits" to channel tax advantaged funds into low cost housing finance, and by measures to prevent institutional failure. These actions have created a patchwork of deliberate market distortions. Selected institutional forms within each country were regulated in relation to 
range of activities, geographic areas of operation, saving and loan products, deposit and mortgage rates, and balance sheets, and often had a distinctive tax framework. Support measures, for home-ownership (see Table 3) also differed across countries.

In the 1990's, these systems were subject to deregulation and technical change, which promoted internally-driven competition. In some cases, the end of exchange controls and the deregulation of funding sources produced considerable system change. The UK, Spain, Finland and Sweden present examples of extensively deregulated housing finance systems, closely integrated with general capital markets, where mortgage systems are rationed by interest rates.

Table 1: Tenure and Public Spending in Housing

\begin{tabular}{|l|l|l|l|l|l|}
\hline Country & $\begin{array}{l}\text { Owner } \\
\text { Occupied }\end{array}$ & $\begin{array}{l}\text { Social } \\
\text { Rented }\end{array}$ & $\begin{array}{l}\text { Private } \\
\text { Rented }\end{array}$ & Other & $\begin{array}{l}\text { Approx. } \\
\text { Cost }^{\text {10 }} \text { of } \\
\text { Housing } \\
\text { Policy (\%) } \\
\text { GDP.) }\end{array}$ \\
\hline Belgium & 67 & 6 & 27 & 0 & $0.2^{11}(1988)$ \\
\hline Denmark & $50(1995)$ & 18 & 18 & $13^{3}$ & $3.6^{12}(1996)$ \\
\hline Germany & 38 & 26 & 36 & 0 & $1.4(1991)$ \\
\hline Greece & 76 & 0 & 24 & 0 & $\ldots$ \\
\hline Spain & 78 & 1 & 13 & $8^{4}$ & $1.1(1990)$ \\
\hline France & 54 & 17 & 21 & $8^{5}$ & $1.8(1993)$ \\
\hline Ireland & 79 & 10 & 8 & 3 & $\ldots$ \\
\hline Italy & 68 & 6 & 18 & $8^{6}$ & $\ldots$ \\
\hline Luxembourg & 70 & $\ldots$ & $26^{2}$ & 4 & $\ldots$ \\
\hline Netherlands & $48(1995)$ & 38 & 14 & 0 & $3.2(1990)$ \\
\hline Portugal & 67 & 3 & 24 & 6 & $\ldots$ \\
\hline UK & $67(1995)$ & 23 & 10 & 0 & $3.3(1993)$ \\
\hline Austria & $54(1995)$ & 20 & 18 & $7^{7}$ & $\ldots$ \\
\hline Finland & $62(1995)$ & 16 & 14 & $8^{8}$ & $1.8^{12}(1996)$ \\
\hline Sweden & 39 & 22 & 22 & $17^{9}$ & $3.9^{12}(1996)$ \\
\hline EU-15 & 56 & 18 & 21 & 5 & $\ldots$ \\
\hline
\end{tabular}

Source: Tenure: Haffner (1998), except Germany, France and EU-15: CECODHAS (1995)

Costs: Denmark, Finland and Sweden: Lujanen (1998)

Germany, France, Netherlands, UK: McCrone \& Stephens (1995)

Belgium: Papa (1992)

Spain: Leal (1992)

Notes:

1. Tenure expressed as \% housing stock; around 1990, unless stated otherwise.

2. Includes small social rented sector

3. Includes vacant dwellings, co-operatively owned dwellings, publicly owned dwellings, and dwellings whose ownership is unknown

4. Includes vacant dwellings, dwellings whose ownership is unknown, and dwellings provided without charge

5. Includes furnished tenancies, subtenancies and dwellings provided without charge

6. Includes dwellings provided without charge

7. Includes official dwellings and dwellings provided as payment in kind 
8. Includes vacant dwellings

9. Includes co-operative sector

10. Includes direct subsidies and tax relief; excludes property taxes

11. Excludes mortgage interest tax relief

12. As $\%$ GNP.

But extensive mortgage market deregulation did not occur everywhere with some countries more resistant to change. In France, deregulation allowed commercial banks to enter the mortgage market after 1987, but restrictions on interest rates remained, removing a vital mechanism for the large credit expansions that occurred elsewhere. French regulators continued to prevent financial intermediaries from paying interest on current accounts and savings accounts of up to three months liquidity. Attempts by foreign banks, notably the British bank, Barclays, to pay interest, were thwarted in the French courts. In consequence, the funding advantage enjoyed by the French deposit-taking institutions left the wholesalefunded mortgage credit companies at a competitive disadvantage.

In Germany, the structure of the mortgage market created by the regulatory system has meant that the abolition of exchange controls has had little impact. The mortgage banks continue to enjoy a monopoly right to issue mortgage bonds, which are still the predominant form of first mortgage. The contract-savings scheme, which can be operated only by Bausparkassen (see Table 2) remains attractive for some, despite the reduction in state support for the system. The market has adjusted to this regulatory regime by becoming vertically integrated, with commercial banks either purchasing or establishing their own Bausparkassen and mortgage banks, and themselves offering top-up loans. This makes the market very difficult to enter for outsiders, domestic or foreign.

Another barrier to entry is the presence of state owned mortgage lenders. These have large market shares in Portugal and Greece, while the German Landesbanken backed by state government provide long-term finance to the savings banks. Thus, the difference in economic histories before 1980 and the different propensities of countries to deregulate thereafter, have left EU countries with very diverse mortgage markets (see Table 2). For instance the maximum loan to value ratios available to borrowers vary from around 40 percent in Italy (see further discussion in Section 4) to 95 percent in the UK.

Further, the extent to which borrowers are exposed to changes in market interest rates varies greatly between countries. Denmark presents one extreme with almost total dependency on mortgages with interest rates fixed for their entire 20-30-year terms, though this appears to have been a relatively recent development (Kennedy,1996). In the UK, what are marketed as 'fixed rate' mortgages, and now represent almost one-third of mortgage debt, are more accurately categorised as 'negotiable' mortgages, since the interest rate is generally 
fixed for no more than five years, while the repayment period is 25 years. Most mortgages in the UK, can be categorised as 'reviewable' since they can be changed at the discretion of lenders. Such borrowers can be exposed to sharp rises in interest rates, as occurred in the UK in 1988-89. In other countries, notably Finland and Spain, the mortgage rate commonly varies automatically in relation to an established index. Historically, mortgages in Finland were linked to the Bank of Finland base rate, which was low and relatively stable. However, from the late 1980s, as funds became linked to market rates, lenders became keener to reduce their exposure to interest rate risk by promoting mortgages with market linked interest rates, see Kosonen (1993); Kosonen and Timonen (1994).

The institutional differences in terms of fixed vs. variable rate mortgage structures are partly explicable in terms of different inflation histories. A high and variable rate of inflation discourages fixed rate borrowing when inflation and nominal interest rates are high because if inflation (and interest rates) were to fall, the borrower would be exposed to higher real debt service costs. When inflation and nominal interest rates are low but fear of future rises remains, fixed-rate lenders are discouraged by the risk of low real loan returns. Therefore, as Spencer (1999) argues, the prevalence of floating rate mortgages in the UK, Ireland, Finland, Spain, Portugal and Greece are partly the result of their inflation histories, though regulation and the type of banking systems which grew up in the different economies play a part too.

These different national housing finance systems, housing policies and patterns of inflation and economic growth have resulted in two further outcomes. First, the ratio of mortgage debt to GDP differs substantially across the European nations, ranging from 6 per cent in Greece and 7 percent in Italy to 65 percent in Denmark, though these figures are not fully comparable (see Table 4).

Secondly, the variety of finance systems and regulatory regimes has resulted in differences in national mortgages, and, more precisely, in intermediation margins. Differences in the efficiency of separate mortgage markets in Europe have been established by Diamond and Lea (1992) for the early 1990's, see Lea et al (1997) for more recent evidence. 
Table 2: Mortgage Systems and Products

\begin{tabular}{|c|c|c|c|c|c|}
\hline Country & Main Lenders & $\begin{array}{l}\text { Interest } \\
\text { Adjustment } \\
\text { (Approx. } \\
\text { Market) }\end{array}$ & $\begin{array}{l}\text { Typical } \\
\text { Term }\end{array}$ & $\begin{array}{l}\text { Typical } \\
\text { Loan-to- } \\
\text { Value Ratio }\end{array}$ & $\begin{array}{l}\text { Repayment } \\
{[R]} \\
\text { Endowment } \\
\text { (E) }\end{array}$ \\
\hline Austria & $\begin{array}{l}\text { Bausparkassen } \\
\text { Mortgage Banks } \\
\text { Savings Banks }\end{array}$ & $\begin{array}{l}\text { Some F } \\
\text { (Bauspar), } \\
\text { mostly N and } \\
\text { R }\end{array}$ & $\begin{array}{l}20-30, \\
\text { Bauspar } \\
10\end{array}$ & $80 \%$ & $\mathrm{R}$ \\
\hline Belgium & Comm. Banks & $\begin{array}{l}\mathrm{N}(75 \%) \\
\mathrm{F}(25 \%)\end{array}$ & $15-20$ & $80 \%$ & $\mathrm{R}$ \\
\hline Denmark & Mortgage Banks & $\begin{array}{l}\text { V }(10 \%) \\
F(90 \%)\end{array}$ & 30 & $80 \%$ & $\mathrm{R}$ \\
\hline Germany & $\begin{array}{l}\text { Bausparkassen } \\
\text { Commercial } \\
\text { Banks } \\
\text { Mortgage Banks } \\
\text { Savings Banks }\end{array}$ & $\begin{array}{l}\mathrm{F}(20 \%, \text { Bau- } \\
\text { spar) } \\
\text { N (40\%) } \\
\text { R (40\%) }\end{array}$ & $\begin{array}{l}25-30, \\
\text { Bauspar } \\
10\end{array}$ & $60-80 \%$ & $\mathrm{R} / \mathrm{E}$ \\
\hline Greece & $\begin{array}{l}\text { Mortgage Bank } \\
\text { Commercial } \\
\text { Banks }\end{array}$ & $\begin{array}{l}\mathrm{F}(30 \%) \\
\mathrm{V}(70 \%)\end{array}$ & 15 & $70-75 \%$ & $\mathrm{R}$ \\
\hline Finland & Comm. Banks & $\mathrm{V}(90 \%)$ & $10-15$ & $70-80 \%$ & $\mathrm{R}$ \\
\hline France & $\begin{array}{l}\text { Comm. Banks } \\
\text { Savings Banks } \\
\text { Mort. Banks }\end{array}$ & $\begin{array}{l}\mathrm{F}(80 \%) \\
\mathrm{V}(20 \%)\end{array}$ & $15-20$ & $70-80 \%$ & $\mathrm{R}$ \\
\hline Ireland & $\begin{array}{l}\text { Building } \\
\text { Societies } \\
\text { Comm. Banks }\end{array}$ & $\begin{array}{l}\mathrm{R}(57 \%) \\
\mathrm{F}(43 \%)\end{array}$ & $20-30$ & $80 \%$ & $\mathrm{R}$ \\
\hline Italy & Comm. Banks & $\begin{array}{l}\mathrm{V}(40 \%) \\
\mathrm{F}(60 \%)\end{array}$ & 15 & $40 \%$ & $\mathrm{R}$ \\
\hline Luxembourg & $\begin{array}{l}\text { Public Banks } \\
\text { Commercial } \\
\text { Banks }\end{array}$ & $\begin{array}{l}\text { Mostly R, } \\
\text { some V. }\end{array}$ & $15-20$ & n.a. & $\mathrm{R}$ \\
\hline Netherlands & $\begin{array}{l}\text { Comm. Banks } \\
\text { Insurance Cos. }\end{array}$ & $\begin{array}{l}\mathrm{V}(10 \%) \\
\mathrm{N}(65 \%) \\
\mathrm{F}(25 \%)\end{array}$ & 30 & $75 \%$ & $\mathrm{E} / \mathrm{R}$ \\
\hline Norway & $\begin{array}{l}\text { Commercial } \\
\text { Banks } \\
\text { Savings Banks } \\
\text { Public Banks }\end{array}$ & $\begin{array}{l}\mathrm{R}(90 \%) \\
\mathrm{N}(10 \%)\end{array}$ & $15-20$ & $80 \%$ & $\mathrm{R}$ \\
\hline Portugal & Comm. Banks & $\mathrm{V}(100 \%)$ & 20 & $80 \%$ & $\mathrm{R}$ \\
\hline Spain & $\begin{array}{l}\text { Savings Banks } \\
\text { Comm. Banks }\end{array}$ & $\begin{array}{l}\mathrm{V}(80 \%) \\
\mathrm{F}(20 \%)\end{array}$ & $15-20$ & $70-80 \%$ & $\mathrm{R}$ \\
\hline Sweden & $\begin{array}{l}\text { Mortgage Banks } \\
\text { Comm. Banks }\end{array}$ & $\begin{array}{l}\text { Mainly R and } \\
\text { short-term N. }\end{array}$ & $20-30$ & $70-75 \%$ & $\mathrm{R}$ \\
\hline $\begin{array}{l}\text { United } \\
\text { Kingdom }\end{array}$ & $\begin{array}{l}\text { Building } \\
\text { Societies } \\
\text { Comm. Banks }\end{array}$ & $\begin{array}{l}\mathrm{R}(70 \%) \\
\mathrm{N}(30 \%)\end{array}$ & 25 & $90-95$ & $\bar{E} / \mathrm{R}$ \\
\hline
\end{tabular}

Source: Lea, et al. (1997)

Notes: Fixed (F) Renegotiable (N), Variable (V) Reviewable (R). Fixed: rate fixed until final maturity. Renegotiable: rate not fixed over entire term, but more than 1 year. Variable: rate adjustable according to index, reference rate. Reviewable: rate adjustable, at discretion of lender. 
Table 3: Approaches to Supporting Home-Owners in European Countries (Circa 1993-4)

\begin{tabular}{|c|c|c|c|c|c|c|c|c|}
\hline & & & & 1993 & & & & 1994 \\
\hline & $\begin{array}{l}\text { VAT on } \\
\text { Repairs }\end{array}$ & $\begin{array}{c}\text { VAT on } \\
\text { New Homes }\end{array}$ & Stamp Duty & $\begin{array}{l}\text { Tax on } \\
\text { Imputed } \\
\text { Rent } \\
\end{array}$ & $\begin{array}{l}\text { Interest } \\
\text { Relief }\end{array}$ & $\begin{array}{l}\text { Relief on } \\
\text { Maintenance }\end{array}$ & $\begin{array}{c}\text { Tax on } \\
\text { Capital } \\
\text { Gains } \\
\end{array}$ & Targete \\
\hline Belgium & $6^{1} ; 20.5$ & 20.5 & $12.5^{2}$ & $\mathrm{Y}$ & $\mathrm{Y}$ & $\mathrm{Y}$ & $\mathrm{P}$ & Low inc \\
\hline Denmark & 25 & 25 & 1 & $\mathrm{Y}$ & $\mathrm{Y}$ & $\mathrm{Y}$ & $\mathrm{P}$ & $\overline{\text { Elderly }}$ \\
\hline Germany & 1.5 & 0 & 2 & $\mathrm{~N}$ & $\mathrm{~N}^{3}$ & $\mathrm{~N}^{4}$ & $\mathrm{P}$ & Low Inc \\
\hline Greece & 18 & - & 10 & $\mathrm{Y}$ & $\mathrm{Y}$ & $\mathrm{N}$ & $\mathrm{N}$ & $\begin{array}{l}\text { Loan } \mathrm{Su} \\
\text { Low Inc }\end{array}$ \\
\hline Spain & 15 & $3 ; 6$ & 6 & $\mathrm{Y}$ & $\mathrm{Y}$ & - & $\mathrm{R}$ & $\begin{array}{l}\text { Low Inc } \\
\text { Young I }\end{array}$ \\
\hline France & 18.6 & 18.6 & $7^{6} ; 10^{7}$ & $\mathrm{~N}$ & $\mathrm{Y}$ & $\mathrm{Y}$ & $\mathrm{P}$ & Home I \\
\hline Ireland & 12.5 & 12.5 & Up to 9 & $\mathrm{~N}$ & $\mathrm{Y}$ & $\mathrm{N}$ & $\mathrm{R}$ & $\begin{array}{l}\text { Variety } \\
\text { e.g. yol } \\
\text { buyers }\end{array}$ \\
\hline Italy & $4 / 19$ & 4 & $8^{6} ; 4.2^{7}$ & $\mathrm{Y}$ & $\mathrm{Y}$ & $\mathrm{N}$ & $\mathrm{N}$ & Improve \\
\hline Luxembourg & 15 & - & - & $\mathrm{Y}$ & $\mathrm{Y}$ & $\mathrm{N}$ & $\mathrm{N}$ & Low inc \\
\hline Netherlands & 17.5 & 17.5 & 6 & $\mathrm{Y}$ & $\mathrm{Y}$ & $\mathrm{N}^{8}$ & $\mathrm{~N}$ & Low Inc \\
\hline Portugal & $5^{9} ; 16^{10}$ & $5^{9} ; 16^{10}$ & 10 & $\mathrm{~N}$ & $\mathrm{Y}$ & $\mathrm{N}$ & $\mathrm{R}$ & Low inc \\
\hline UK & 17.5 & 0 & 1 & $\mathrm{~N}$ & $\mathrm{Y}$ & $\mathrm{N}$ & $\mathrm{N}$ & $\begin{array}{l}\text { Home I } \\
\text { Low-co: }\end{array}$ \\
\hline Austria & $10-20$ & $10-20$ & 3 & $\mathrm{~N}$ & $\mathrm{Y}$ & - & $\mathrm{P}$ & $\overline{\text { Low Inc }}$ \\
\hline Finland & 2211 & $22^{11}$ & 6 or $1.6^{12}$ & $\mathrm{~N}$ & $\mathrm{Y}$ & $\mathrm{N}$ & $\mathrm{P}$ & $\begin{array}{l}\text { First-tin } \\
\text { families }\end{array}$ \\
\hline Sweden & 25.0 & 25.0 & 1.5 & $\mathrm{~N}$ & $\mathrm{Y}$ & $\mathrm{Y}$ & $\mathrm{Y}$ & Home I \\
\hline
\end{tabular}

Sources: This table is based on a questionnaire organised by the ENHR Housing Finance Working Group in 1995. It has been suppl Department of the Environment and Local Government (Dublin) (1988), Hedman (1993), Hills (1998), McCrone and Stephens (199 (1993) and responses from academics and civil servants in Belgium, Germany, Spain, Ireland, the Netherlands, Portugal, Austria, Finla

Y=yes; $\mathrm{N}=0$; $\mathrm{P}=$ if resold in a short period; $\mathrm{R}=$ roll-over relief; -=not known

Notes: 1. If property aged over 20 years; 2. Basic rate; real rate is higher with regional variations; 3 . Relief was applied temporarily on new house specific circumstances, e.g. for energy savings measures and in development areas; 5. Major changes are expected; 6. Estimate by ENHR; 7. Estim (1993); 8. A standard deduction for maintenance and depreciation is applied when calculating the tax on imputed rent; 9 . This lower rate is applied 1 regulated prices; 10 . This standard rate has since been raised to $17 \% ; 11$. Introduced in $1994 ; 12.6 \%$ for single family homes; 1.6 for other dwellings 
Table 4: Importance of Mortgage Credit in National Economies

\begin{tabular}{|l|c|}
\hline Country & $\begin{array}{c}\text { Outstanding residential mortgage debt as } \\
\text { \% GDP }\end{array}$ \\
\hline Belgium & 22 \\
\hline Denmark & 65 \\
\hline Germany & 51 \\
\hline Greece & 6 \\
\hline Spain & 22 \\
\hline France & 21 \\
\hline Ireland & 27 \\
\hline Italy & 7 \\
\hline Netherlands & 60 \\
\hline Portugal & 26 \\
\hline UK & 57 \\
\hline Finland & 30 \\
\hline Sweden & 51 \\
\hline Austria & $30-33$ \\
\hline EU-15 & 36 \\
\hline
\end{tabular}

Source: European Mortgage Federation (1998).

Notes: EMF data are mortgage loans for owner-occupation and rental purposes but are not fully comparable. For example, the degree to which social housing is mortgage financed varies. In some countries, unsecured housing loans are included, in others not.

The estimate for Austria is by Edwin Deutsch (Technical University, Vienna).

Table 5: Transaction Costs and Labour Mobility

\begin{tabular}{|l|c|c|c|}
\hline Country & $\begin{array}{c}\text { Total Transaction } \\
\text { Cost as \% Price }\end{array}$ & $\begin{array}{c}\text { Taxation Tax as \% }^{\mathbf{1}} \\
\text { Price }^{\mathbf{1}}\end{array}$ & $\begin{array}{c}\text { Inter-regional } \\
\text { Mobility (\% } \\
\text { population) }\end{array}$ \\
\hline Spain & 1993 \\
\hline France & 10.4 & 6.0 & 0.56 \\
\hline Germany & 13.8 & 10.0 & 1.07 \\
\hline Italy & 7.1 & 2.0 & 1.23 \\
\hline UK & 7.4 & 4.2 & 0.50 \\
\hline US & 2.0 & 1.0 & 1.58 \\
\hline
\end{tabular}

Source: Transaction costs and taxes, except USA: Woolwich Building Society (1993); USA: Economist (1992). Inter-regional mobility: Eurostat (1996; 1997). USA: OECD.

Notes:

1. on $£ 80,000$ property

2. 1993, except USA, 1987. 


\subsection{Transaction Costs}

We turn now to the third element where important country differences affect the role of housing in the interest rate transmission process. Table 5 gathers some international evidence, which is unfortunately not available for all 15 EU countries. ${ }^{13}$ Note however, that Table 3 contains information on Stamp Duty on housing for the full range of EU countries, which is one element of transactions costs.

On the basis of these institutional differences between countries, it is now possible to make some predictions both on the volatility of real house prices and on the connection between real house prices and consumption. We have argued that the countries with high transactions costs, low loan-to-value ratios, a small owner-occupied sector, a large tenure proportion in the private rented sector, and a large proportion of fixed interest mortgage loans, should experience relatively low real house price volatility ${ }^{14}$, small house price effects on consumption and a small role for housing in the interest rate transmission mechanism.

\subsection{Evidence on House Price Volatility and on the House Price-Consumption Link}

Table 6 provides recent evidence on real house price fluctuations. However, there are serious comparability problems in these data. Few indices are properly mix-adjusted and representative of national housing market transactions. The inner areas of large cities often

13 Since the migration-mobility link will also be discussed in Section 5, the Table includes some evidence on mobility too.

14 The relative volatility prediction assumes similar income and population growth, and similar changes in demographic structure and housing supply. Potentially, differences in the flexibility of housing supply due to the land-use planning system could account for a considerable part of volatility differences between countries. 
Table 6: Movements in Real House Prices in European Union Countries (percentage chan:

\begin{tabular}{|c|c|c|c|c|c|c|c|c|c|c|c|c|}
\hline & Belgium & Denmark & Germany & Greece & Spain & France & Ireland & Italy & $\begin{array}{l}\text { Luxem- } \\
\text { bourg }\end{array}$ & $\begin{array}{l}\text { Nether- } \\
\text { lands }\end{array}$ & Austria & Portu \\
\hline 1986 & 5.0 & 11.0 & 2.0 & 0.0 & -2.0 & $\begin{array}{l}\text { A } 5.1 \\
\text { B } 1.0\end{array}$ & 0.0 & $\begin{array}{l}\text { A - } \\
\text { B - }\end{array}$ & 4.0 & 5.0 & - & $\mid-1.0$ \\
\hline 1987 & 2.9 & -1.8 & 1.0 & 3.0 & \begin{tabular}{|l|}
17.3 \\
\end{tabular} & $\begin{array}{l}\text { A 5.9 } \\
\text { B } 1.0 \\
\end{array}$ & 3.0 & $\begin{array}{l}\text { A - } \\
\text { B 1.0 }\end{array}$ & 3.8 & 4.8 & - & \begin{tabular}{|l|}
-2.0 \\
\end{tabular} \\
\hline 1988 & $4.8^{*}$ & $-1.7^{*}$ & 1.0 & 2.9 & $20.2^{*}$ & $\begin{array}{l}\text { A } 7.4 \\
\text { B }-6.9\end{array}$ & $7.5^{*}$ & $\begin{array}{l}\text { A - } \\
\text { B - }\end{array}$ & 0.9 & $3.7^{*}$ & - & \begin{tabular}{|l|}
0.0 \\
\end{tabular} \\
\hline 1989 & 8.9 & -4.8 & 1.0 & 1.9 & 17.5 & $\begin{array}{l}\text { A } 7.4 \\
\text { B } 10.5\end{array}$ & 7.2 & $\begin{array}{l}\text { A - } \\
\text { B 24.6 }\end{array}$ & 2.8 & 5.4 & - & $\mid-1.0$ \\
\hline 1990 & 4.1 & -10.9 & 3.7 & 0.9 & 8.2 & $\begin{array}{l}\text { A } 5.1 \\
\text { B } 13.3^{*}\end{array}$ & 9.0 & $\begin{array}{l}\text { A } 15.2 \\
\text { B } 18.9\end{array}$ & $1.5^{*}$ & -0.4 & - & $-0.4^{*}$ \\
\hline 1991 & 2.8 & -1.4 & $2.8^{*}$ & 0.9 & \begin{tabular}{|l|}
8.1 \\
\end{tabular} & $\begin{array}{l}\text { A } 0.7 \\
\text { B -3.6 } \\
\end{array}$ & -1.2 & $\begin{array}{l}\text { A } 6.2 \\
\text { B } 5.6\end{array}$ & 1.7 & -0.1 & 5.0 & \begin{tabular}{|l|}
-0.5 \\
\end{tabular} \\
\hline 1992 & 6.1 & -8.0 & 0.9 & -5.6 & \begin{tabular}{|l|}
-6.7 \\
\end{tabular} & $\begin{array}{l}\text { A }-2.0 \\
\text { B }-8.1 \\
\end{array}$ & -0.1 & $\begin{array}{l}\text { A } 1.1 \\
\text { B } 0.8 \\
\end{array}$ & 3.7 & 4.6 & 5.7 & 5.1 \\
\hline 1993 & 4.2 & -5.1 & 1.2 & -3.9 & \begin{tabular}{|l|}
-5.5 \\
\end{tabular} & $\begin{array}{l}\text { A }-1.0 \\
\text { B }-0.4\end{array}$ & -0.5 & $\begin{array}{l}\text { A }-5.7 \\
\text { B }-3.4\end{array}$ & -2.2 & 7.3 & 6.3 & 5.7 \\
\hline 1994 & 4.9 & 4.9 & -0.9 & - & \begin{tabular}{|l|}
-3.8 \\
\end{tabular} & $\begin{array}{l}\text { A } 1.6 \\
\text { B } 1.1\end{array}$ & 2.3 & $\begin{array}{l}\text { A }-6.7 \\
\text { B }-7.2\end{array}$ & -1.0 & 4.6 & 5.1 & 5.9 \\
\hline 1995 & 3.0 & -2.1 & -0.8 & - & -1.2 & $\begin{array}{l}\text { A }-2.7 \\
\text { B }-6.1 \\
\end{array}$ & 3.8 & $\begin{array}{l}\text { A }-3.8 \\
\text { B }-3.7 \\
\end{array}$ & -0.1 & 1.9 & 3.2 & 1.7 \\
\hline 1996 & 2.2 & $7.2^{*}$ & -1.5 & - & \begin{tabular}{|l|}
-1.0 \\
\end{tabular} & $\begin{array}{l}\text { A }-0.4 \\
\text { B }-9.0\end{array}$ & 10.3 & $\begin{array}{lr}\text { A } & 0.2 \\
\text { B } & -3.9 \\
\end{array}$ & -0.5 & 8.3 & 1.6 & 8.3 \\
\hline $1997^{* *}$ & -0.2 & 6.3 & -2.6 & - & \begin{tabular}{|l|}
-1.2 \\
\end{tabular} & $\begin{array}{ll}\text { A } & 0.0 \\
\text { B } & -3.2\end{array}$ & 15.2 & $\begin{array}{l}\text { A -7.8 } \\
\text { B - }\end{array}$ & 0.1 & 5.8 & 3.1 & 4.6 \\
\hline $\begin{array}{l}\text { Standard } \\
\text { Deviation }\end{array}$ & 2.2 & 6.6 & 1.8 & 3.1 & \begin{tabular}{|l|}
9.4 \\
\end{tabular} & $\begin{array}{l}\text { A } 4.1 \\
\text { B } 7.0\end{array}$ & 5.1 & $\begin{array}{l}\text { A } 7.8 \\
\text { B } 11.6\end{array}$ & 2.0 & 2.6 & 1.7 & 3.5 \\
\hline
\end{tabular}

Source: as specified in notes

$* \quad$ possible discontinuity in series $* * \quad$ estimated or for part of year 
Notes: the main sources are annual reports of the European Community Mortgage Federation (ECMF) for data up to 1990 and of the European Mortgage Federation (EMF) for data from 19881997, which do not always described the indices in detail. For Belgium, Denmark, Spain, the Netherlands, Austria, Italy, Finland, Sweden and the UK the indices appear to be mainly based on prices of existing houses. However, for Austria they appear to be mainly based on Vienna and for Italy on the main cities. The data for Italy come from two sources: (A) Osservatorio sul mercato immobiliare,Nomisma which refer to average prices in the 13 largest cities, and (B) from EMF (1998,Table 7). For Ireland, the data refer to new houses. For Germany, Luxembourg, Greece and Portugal the data are construction price indices. However, data from German real estate agents (Ring Deutscher Makler) are also consistent with low volatility. Data for France are: (A) for the IPT (indice de prix des transactions) a national index for a range of housing types computed at INSEE by synthesizing data from multiple sources. The (B) data come from the European Monetary Institute (1998), which provides no documentation. Data for Finland and Sweden in 1986-7 come from the Norwegian Building Research Institute. The UK data are the mix-adjusted series for all houses from the Department of the Environment, Transport and the Regions. Note on price deflator: ECMF/EMF do not specify by which index prices were deflated; all other prices deflated by CPI, except Finland and Sweden 1988 and 1989 using price deflator of private consumption

have much more volatile price movements than the country average. ${ }^{15}$ Using a standard deviation as an indication of volatility, the data do suggest that the countries most evidently in the DM zone (Germany, Austria, and Benelux) have the lowest levels of volatility. These countries tend to conform to the pattern of below average owner occupied sectors (Germany, Austria, and the Netherlands), or above average owner occupied sectors balanced by above average market rental sectors (Belgium and Luxembourg). Germany is characterised by both a small owner occupied sector and a large market rental sector. Among the southern European countries, as far as their poor data allow any conclusions to be drawn, Portugal and Greece seem to have avoided price volatility, and Greece in particular has low loan-to-value ratios.

The data also suggest that the countries that experienced greatest mortgage market liberalisation in the 1980s, experienced the greatest price volatility. Sweden, Finland and the UK each had well-documented house price booms and busts following deregulation. Spain too experienced a strong house price boom in the late 1980s, but was alone in this group of countries in avoiding significant falls in nominal house prices. The price booms in each of

15 The comparability problems are well illustrated by the data for France. The best available and most comprehensive data from INSEE, marked (A) in Table 6, and not available to us at the time the earlier version of this article went to press, differ radically from the European Monetary Institute data, marked (B). Circumstantial evidence suggests that from 1990 the latter data may be for prices of appartments in Paris. 
these countries coincided with very large expansions in mortgage credit, Stephens (1995) and Borio (1997).

As far as evidence on the real house price to consumption link is concerned, the biggest international comparison was undertaken by Kennedy and Anderson (1994). For 15 countries, they estimated equations for the saving ratio, including as explanatory variables income growth, interest rates, the unemployment rate and changes therein, the level and change in current real house prices and in the household debt to income ratio (to proxy the effects of financial liberalization). Unfortunately, their estimates are contaminated by endogeneity bias: only beginning of period house price and debt data should have been used. ${ }^{16}$ Nevertheless, they offer some guide. For Norway, Denmark, Finland, UK and the Netherlands they imply substantial positive real house price level effects on consumption, ${ }^{17}$ while these effects are absent for Germany, France, Italy, Belgium, Ireland and Sweden ${ }^{18}$ (Spain, Portugal, Greece and Austria are not in the sample). Germany, France, Italy and Belgium all have at least three of the four characteristics which predict a low effect: relatively high transactions costs, low loan-to-value ratios, a low level of owner-occupation and a high proportion of households in the market rented sector. Norway, Denmark, Finland and the UK have at most one of these characteristics. Thus, though there are problems both with the econometric specification and data quality, the evidence is broadly consistent with the hypothesis.

The main large UK macroeconometric models now all include significant housing wealth effects as do those of the central banks of Norway, Sweden and Finland. In the UK, thanks to the work of Geoff Meen, see Meen (1996), the Oxford Economic Forecasting model contains the most fully articulated treatment of the multiple interfaces through which housing interacts with the wider economy.

16 In other respects, these equations are also some way from well specified saving or consumption functions which should include disaggregated wealth effects as well as a proxy for expected income growth and should distinguish non-property income from total disposable income, see Muellbauer and Lattimore (1995).

Though, given the correlation between financial liberalization and house prices which can complicate the separation of the two effects, they appear to have over-estimated the former effect at the expense of the latter for the UK, with the reverse bias in Norway.

18 Sweden exhibits very large debt effects and a large positive effect from the change in house prices, making this conclusion somewhat suspect. 
Germany, France and Greece have high proportions of debt which is fixed for the entire repayment period, or for a sufficient period to provide some protection against interest rate rises. Finland and the UK have predominantly floating rate mortgage markets (i.e. the interest rate on the bulk of mortgage may be varied at the discretion of the lender of automatically according to an index), suggesting large transmission effects on consumption for these countries. The same is true of Ireland, although it now has a substantial block of fixed rate mortgages.

\subsection{Differences in Public Debt Markets, Pension Systems and Corporate Finance}

As noted in Section 2 and by Kneeshaw (1995), differences between countries in financial asset to income ratios for households will result in differences in the interest rate transmission process via financial asset prices. Table 7 gives recent data on market capitalization to GDP ratios of bonds and equities for the major European economies. These do not translate one for one into similar ratios for the personal sector, largely because foreign ownership patterns differ. Nevertheless, one would expect a considerable correlation between the two. France, Germany and Italy, whose stock market capitalizations are still relatively small and where pensions systems are still largely of the pay-as-you-go type, can be expected to have relatively small equity to income ratios, as Kneeshaw (1995) confirms. In Italy, with its historically high savings rate and its huge government debt, households own large amounts of this debt. Given income expectations, this constitutes net wealth, pace Barro (1974) though any increase in the indebtedness of the government would, no doubt, be seen to have negative implications for future disposable income. The UK and the Netherlands, with more developed funded pension systems, can be expected to have large asset to income ratios and, ceteris paribus, large interest rate transmission effects via this route.

Some international evidence on financial wealth effects on consumption is given in Barrell et al (1991). This confirms larger effects for the UK than for Germany and France. However, the long-run solution for Italy is too poorly specified to allow reliable conclusions to be drawn here.

One important implication which this research supports, together with the higher proportions of employment in financial services in the UK, is that fluctuations in world equity prices will have bigger effects on the UK than on the core EMU economies. 
There is already a significant literature on differences in corporate finance across Europe. $^{19}$ The main points are the following. Equity finance is biggest in the UK. In continental Europe, banks typically account for 80 percent or more of the debt liabilities of non-financial companies but only around 50 percent in the UK. Banks in the UK and Sweden more than in continental Europe rely on collateral in their lending practices. 'Relationship banking' appears to be more important in Germany, France and Italy. Another symptom of this is that there is a slower response of bank short-term overdraft rates to shortterm interest rates in these countries. In Italy and France, this seems to partly compensate for the low proportion of bank lending to firms which is at fixed rates. In Germany, a large fraction of lending to firms is at fixed rates, and for the rest, variable rates adjust only slowly to the rates over which the central bank has most influence. Together with similar institutional differences to these across countries for households, the implication should be one of smaller and more sluggish responses of final expenditure and output to rises in shortterm interest rates in Germany, compared with the UK.

Table 7: Financial Market Capitalization to GDP Ratios in 1995/6

\begin{tabular}{|l|c|c|c|}
\hline & Domestic Debt Securities & $\begin{array}{c}\text { International Debt } \\
\text { Securities }\end{array}$ & Equities (\%) \\
\hline Austria & 63 & 27 & 14 \\
\hline Belgium & 154 & 10 & 38 \\
\hline Denmark & 167 & 19 & 33 \\
\hline Finland & 73 & 43 & 35 \\
\hline Germany & 78 & 6 & 24 \\
\hline Greece & 70 & 15 & 12 \\
\hline France & 81 & 12 & 32 \\
\hline Italy & 151 & 6 & 19 \\
\hline Ireland & 49 & 46 & .a. \\
\hline Netherlands & 69 & 58 & 73 \\
\hline Portugal & 61 & 12 & .a. \\
\hline Spain & 58 & 5 & 26 \\
\hline Sweden & 126 & 46 & 70 \\
\hline UK & 60 & 31 & 124 \\
\hline
\end{tabular}

Source: Funke and Kennedy (1997).

19 See BIS (1995), Borio (1997), McCauley and White (1997), Prati and Schinasi (1997), and Dornbusch et al (1998). 
Finally, to comment on a potential mechanism via the government deficit, Italy's huge government debt has a relatively short-term maturity structure. In the last ten years, when Italy has been struggling to deal with this, and more recently to meet the Maastricht preconditions on entry to EMU by debt reduction and a reduced government deficit, it seems likely that a rise in short-term rates would have raised the deficit and so led to fiscal tightening and hence a negative effect on expenditure and output.

It is conceivable that this effect could help account for the finding reported by Dornbusch et al (1998) on monthly data for 1985 to 1995, that Italy had the highest negative response of output to short-term interest rates. However, as we have earlier pointed out, the VAR methodology on which are based the often highly divergent claims of many researchers on differences in the monetary policy transmission mechanism across Europe, is seriously deficient. This point is now explained in more detail.

Gerlach and Smets (1995) and Barran et al (1997) use a trivariate model in output, inflation and the short-term interest rate. That is, the VAR consists of an estimated linear model relating current values of each variable to lags of itself and the other two variables. Subject to certain 'identification' restrictions, e.g. the assumption that changes in interest rates have no long-run effect on output, the residuals can be interpreted to be combinations of underlying monetary policy shocks, supply shocks etc. Given such a structural interpretation, it is then possible to simulate the responses of the variables to what are interpreted as monetary policy shocks, holding all the other shocks to zero. The resulting 'impulse response functions' trace the time paths of these responses.

This approach is subject to a number of serious criticisms. The first is misspecification because of the omission of important variables. Asset prices, including the exchange rate are omitted, as are fiscal variables, oil price shocks and US interest rates, output and inflation. This is likely to mean that the so-called monetary policy shock component in the equation residual is complex mixture of the omitted variables and may have little to do with domestic monetary policy.

A second problem is that the Lucas critique applies even more strongly to VAR's than to macroeconometric models, which at least attempt to build in some economic theory, institutional knowledge and previous research findings in specifying sectoral relationships.

Britton and Whitley (1997) attempt to meet the first criticism by estimating a much richer model including the money stock, imports and exports, the nominal exchange rate, a long interest rate and two exogenous variables, oil prices and tax rates, as well as output, 
inflation and the short rate. However, they run head-on into the second criticism. They estimate their model over the 1964-94 period. During this time, the Bretton Woods system of semi-fixed exchange rates collapsed in the early 1970s. The 1980s saw major structural changes: monetary policy moved away from various kinds of quantitative attempts to control credit expansion to a market based system. This paved the way for the financial liberalization of the 1980s with major consequences for consumer behaviour discussed in Section 4. Fiscal policy went through the Thatcher revolution causing a major shift in fiscal policy feedback rules, embodying a much greater concern with deficits and government debt. Also, UK labour market flexibility increased. Since the VAR is a reduced form, reflecting the whole system of economic relationships, it is hard to conceive that it could have remained stable over this whole period.

The third problem concerns the basic methodology. Sims $(1980,1992,1996)$, who is the major proponent of the methodology, wants to avoid causal confusion of the kind symbolized by the question: “does the cock's crow cause the sunrise?", Sims (1992). Or to put it another way, if we observe short-term interest rates rise 9 months before output growth slows down, how much of the output decline can be attributed to a tightening of monetary policy? Those who follow the "identified VAR" approach attempt to separate out a component in the residuals or "shocks" to the system which they call a monetary policy shock. However, this runs the serious risk of trivialising the effects of monetary policy. ${ }^{20}$

To explain why, consider the following situation. Suppose that over the period the VAR is estimated, the central bank rigorously follows a feedback rule, perhaps a variant of the Taylor (1993) rule linking short-term interest rates with the output gap and current or forecast inflation. $^{21}$ The stochastic errors or shocks in this relationship would then reflect observation errors in output and inflation and perhaps short-run problems with the controllability of interest rates. The identified VAR methodology would see these trivial shocks as "monetary policy". This would miss completely the important question: how would output, inflation, etc. have behaved if a DIFFERENT policy feedback rule had been followed, for example setting the rate according to past inflation. ${ }^{22}$ Only by simulating the

20 See Cochrane (1994) for more discussion of the identification problem in VAR's.

21 This is an oversimplified example, since one might imagine pressure from foreign interest rates as well in small open economies.

22 Similar points are made by Bernanke et al (1997) and Rotemberg and Woodford (1997). The latter provide evidence that on quarterly US data, only around $5 \%$ of the variability of the monetary 
system with the two alternative feedback rules and comparing the results can this sort of question be answered. But this clearly requires the estimation of at least one structural relation, namely the policy feedback rule. Indeed, the Lucas critique would imply that this was insufficient since, had the feedback rule been different, the other components of the reduced form VAR would have been different. It is inescapable that a structural systems approach is needed to answer this type of question.

This suggests that improving the theoretical and econometric specification of macroeconometric models to articulate fully the transmission channels discussed in Section 2, treat expectations systematically and handle structural breaks due to policy regime shifts, is a better alternative to abandoning them in favour of VAR's.

\section{Barriers Against Convergence in Financial Systems after EMU}

The Introduction discussed some of the pressures for economic convergence: these include the deepening of increasingly integrated corporate bond and equity markets, fiscal and demographic pressures on governments to move towards funded pension systems, and increased cross-border competition in banking and insurance. Such evolution of institutions and practices would be bound to have an effect on behaviour, making it particularly difficult for the ECB to manage monetary policy.

Many economists take it for granted that convergence of financial systems under EMU will occur fairly rapidly and completely. However, this section, based on preceding discussion and evidence, will show that there may be considerable blockages to such convergence, which may occur slowly and by different degrees in different countries; if at all, in some cases.

If increased competition under EMU were to lead to the kind of financial liberalization of credit markets experienced in the UK and Scandinavian countries in the 1980s, the research reported in Muellbauer and Lattimore (1995) and Muellbauer and Murphy (1995), suggests the following behavioural changes for household consumption:

1) a reduction in the percentage of credit-constrained households;

2) increased spendability of illiquid assets since their use as collateral has expanded, with debt behaving like negative liquid assets;

instrument is explained by the feedback rule. The point is implicit in Taylor (1995) who defines a shift in monetary policy by a parameter shift in the feedback rule rather than by a 'monetary policy shock'. 
3) the reduction in the "saving for a housing down-payment" motive is likely to reduce the household saving rate permanently;

4) the consumption response to the real interest rate and to income growth expectations should increase;

5) financial liberalization should therefore itself contribute to the shifts in the income expectations generating mechanism (e.g. financial liberalization could alter the response of expenditure and income growth to interest rates).

One question then is how extensive and rapid will be the growth of consumer credit under EMU? Under the European Union's Single Market programme (1987-92), legislation was introduced to facilitate cross-border competition in a range of banking, including mortgage services. The Second Banking and related Directives required all institutions to meet common prudential standards, that lenders be allowed to lend in all Member States on the basis of the banking licence issued in the home state (the so-called single passport), and that lenders operate in the same way at home and abroad.

In principle, one might have expected that the single passport would have led to a single market in mortgage finance, with different systems converging on the most efficient system through actual cross-border competition and the threat of such competition. However, in practice there is, to date, very little evidence of convergence in mortgage markets (see Section 3). Cross-border operations by lenders have been small-scale and often unsuccessful, while mortgage markets remain overwhelmingly dominated by domestic institutions, see McCrone and Stephens (1995), ch. 10.

The reason is, that until now, a number of factors have operated against the creation of a single market, quite aside from the obvious issues of language, culture, exchange costs and risks. Mortgage products are difficult to standardise. For example, British and Dutch tax arrangements favour endowment products whereas the Spanish tax system favours repayment mortgages. Mortgage security is also nation-specific, as valuation systems and national laws lead to difference in foreclosure arrangements (see above). In some countries, state owned banks, having access to cheaper funds because of their greater security, persist. Other domestic institutions may retain regulatory advantage, for whilst the Single Market Treaty and directives prevents discrimination against foreign entrants, they does not preclude favouring particular institutional types. For instance, a British lender seeking to successfully compete in Germany would probably have to establish (or purchase) a mortgage bank. However, market entry is expensive, especially for deposit-taking lenders using extensive branch networks. Entry may be more feasible for centralised lenders using wholesale funds, 
but such funds are not always cheaper than retail sources and centralised lending usually precludes the cross-selling of other financial products.

While EMU is reducing distortions in savings markets (so reducing some lenders' funding advantages) and is creating more transparent mortgage pricing, significant institutional barriers remain to the creation of pan-European mortgage products and a fully integrated mortgage market (see Stephens, 2000). Amongst the most important are legal and institutional barriers to the use of housing as collateral. This is most evident in Italy, where possessions proceedings by a mortgage lender to obtain the title to the property of a borrower in default can take up to six years, and where the outcome is typically far from certain. Lea et al (1997) and Guiso, Japelli and Terlizzese (1992) argue that this is a major reason why loan-to-value-ratios in Italy are under 50 percent and why the mortgage debt to GDP ratio is so low. These legal difficulties appear to be associated with a general lack of competition and efficiency in the Italian legal system, and perhaps also with lack of rationalization in the system of land title registration. To what extent there may be similar issues in other European countries has proved extraordinarily difficult to establish, though Lea et al (1997) suggest that possessions are also subject to significant delays in France and Spain. In most countries, unlike the US and the UK and to some extent Spain, mortgage lenders appear to be most unwilling to release information on mortgage default statistics. In part this may be that in countries with fixed interest rates, low loan-to-value ratios and fairly stable house prices, defaults are extremely rare events.

Some would argue that another contributory factor to the low mortgage debt to income ratios seen in Italy is crowding out in the debt markets by the huge government debt. It may be that as government debt decreases under EMU, there will be increasing pressure on the legal and administrative system to allow housing to be more efficiently used as collateral. No doubt there is also scope for government action to bring about reform more swiftly.

In the context of Italy, the economic and social consequences of liberalization are likely to be profound, and may take a generation to work through. The Italian pattern of high household saving rates, low debt to income ratios, a late average age of first purchase of a home (the children often living with their parents into their thirties), and the importance of transfers within extended households, interlocks with the legal and institutional barriers mentioned above. It seems likely indeed that the peculiar Italian housing situation where, in addition, rent controls have only relatively recently been abolished for new tenants, has influenced the birth rate and so bears some responsibility for the extremely unfavourable ratio Italy now has and can expect of the ratio of numbers of people of pension age to people of 
working age. Along with its high public debt to income ratio, Italy has the most unfavourable ratio among EMU members of public pension obligations to income, see Kopits (1997) and Hamann (1997), though the government continues with its reform programme

If and when the barriers to an efficiently functioning legal, credit and housing system are dismantled, there could be major falls in household saving rates along with government debt to income ratios, and rises in household debt to income ratios. On the other hand, public pension reforms should lead to offsetting rises in personal saving and many observers agree this has restrained consumption growth in Italy in recent years. Managing these processes without significant economic instability and without having resort to domestic monetary policy instruments, will require not only skill, but considerable luck on the part of Italian policy-makers.

Having appraised some of the important constraints to institutional convergence in these markets, it is clear that innovation and competition will increase, and fairly rapidly in some niches, bringing benefits to consumers where the barriers to entry are less extreme.

\section{Housing and the Supply Side}

The housing tenure structure, summarized in Table 1, has several implications for the supply side, especially labour mobility within Europe. The social housing sector has, since the 1970s, increasingly become the home for semi-skilled and unemployed households, and these are the groups likely to be disproportionately affected by asymmetric regional decline. In general, unemployment rates for social sector tenants in the EU now run at two to three times national averages. A recent overview (Maclennan, Stephens and Kemp, 1997) indicates that, typically, rents are set 30 to 40 percent below market levels. These subsidies are not portable and they are tied to particular dwellings. In addition, as social rent increases have widely outstripped inflation in most countries, rising proportions of social sector tenants receive (nationally determined and variable) ex post income-related benefits. For instance, such allowances are paid to just under half of French social tenants and almost three-quarters of UK tenants. Such schemes invariably have work-disincentive or poverty-trap effects for unemployed households. In consequence, in regions (nations) of economic decline, which usually have above-average social sector shares, social rents do not fall with reducing labour demand, and tenants may have little incentive to move to employment. Fiscal bills for nationally-financed allowances are rising in such areas. 
Even if European tenants do seek to move, European housing systems often have municipal boundaries making it difficult to move within the nation. Cross-national moves, though little research exists on this topic, are likely to be few. In many countries, private rental systems, though subject to deregulation in seven of the fifteen Member States have since around 1990 offered limited market alternatives. However, rent changes are widely regulated and market access is often problematic (Maclennan et al, 1997).

European home-ownership arrangements are also unlikely to promote mobility. Price differences across nations and regions are likely to mean that those moving to growing regions will be confronted by large 'trading-up' gaps. In addition, reflecting differences in national taxation, valuation, property selling and legal systems, the transaction costs associated with moving home in Europe are markedly high by advanced economy standards (see Table 5). Only the UK has a transaction system for owner-occupiers less costly than the US, though offset in its implications for overall mobility by mobility restrictions on social housing tenants. Unsurprisingly, regional labour mobility (and even more so, cross-national mobility) is markedly lower in Europe than in the US.

The key points of the above paragraphs are obvious and telling. Housing arrangements in Europe are not price-flexible and conducive to mobility, and are likely to preclude effective labour market adjustment across European countries, let alone within them. Ignoring these concerns in theoretical discussion, which so much relies on effective labour mobility, is careless, but ignoring them in the real European debate constitutes gross neglect. The European Union, to ease the adjustment difficulties post currency integration, must take a view on the economic role and functioning of housing systems in cross-regional integration. At present housing remains a small and back-door interest of the Social Affairs Division of the Commission. The message is clear: inflexible housing systems may be as important as inflexible wage mechanisms in preventing the required adjustment within the Union.

\section{Conclusions, Policy Implications and Evidence}

We have discussed the mechanisms by which changes in short-term interest rates impact on expenditure and inflation. One of the most important of these is via asset prices. Differences in institutions across Europe (which we have amply demonstrated) imply substantially different responses both to interest rate changes and to world-wide equity price changes as experienced in recent years. Though institutional differences are multi-dimensional, the 
tendency is for countries to have a cluster of high response or low response characteristics. The UK represents one extreme in many dimensions. Together with Ireland, its pension system has the largest funded proportion, see Roseveare et al (1996), making consumer spending more sensitive to changes in financial asset values. It has a high rate of owneroccupation, a small market rented sector and the lowest housing transactions costs in Europe, even after two rises in Stamp Duty. Its consumer credit system, in which housing collateral plays a key role, is highly developed, resulting in high levels of gearing. Housing wealth effects on consumption are therefore large. Most mortgage debt is floating rate debt and so highly sensitive to short-term interest rate movements. Given this combination of characteristics, house prices therefore tend to be volatile, given to overshooting and responsive to interest rates, though with variable lags and intensities. Bank lending to companies is similarly collateral-based and overdraft rates are fairly responsive to short-term interest rates. Equity finance is more important to companies than elsewhere in Europe.

Simulations with large macroeconomic models show larger interest rate effects on output in the UK, consistent with the findings predicted by economic reasoning. ${ }^{23}$ The fact that research using VAR methodology has arrived at less conclusive results has persuaded some economists that these are minor issues. However, as we have argued in Section 3, this research using VAR's is seriously flawed.

France and especially Germany are in many respects close to the other end of the spectrum, though Italy has even higher transactions costs and an even less developed consumer credit system. In Italy, housing has only a small collateral role, essentially because inefficiencies in the legal system make possession by the lender in the case of a loan default impractical. Sweden, Ireland and in particular Finland, are closer to the UK-end of the spectrum, with the Netherlands and Spain in an intermediate position.

Though there are pressures on pension systems, corporate finance systems and consumer credit markets to move in the direction of the UK, there are also strong forces of resistance in some countries, not only in pension reform, see Kopits (1997), Hamann (1998) and Miles (1998), but particularly in housing finance and housing tenure. It seems likely that even a decade after monetary union, the systems will be far from homogenous. Nevertheless, the forces for credit market liberalization could set off significant consumer-led expansions in

23

It is unclear whether greater labour market flexibility in the UK amplifies or diminishes this difference. But here is evidence that employment and investment in Germany and France respond to shocks with longer lags than prevalent in the UK. 
several countries, as well as leading to profound shifts in behavioural relationships explained in Section 4. The ECB will find it hard to deal with these and other behavioural shifts which are the direct or indirect result of monetary union, as well as with the tensions created by asymmetric responses to interest changes and world asset price shocks. Indeed, to the extent that the ECB inherits not only the Bundesbank's anti-inflationary credibility but its view on how the (German, now the European) economy functions, significant policy errors can be expected.

If the ECB is to monitor macroeconomic developments in the member states, major improvements will be needed in many countries in the national and sectoral financial accounts, including the integration of market value estimates of physical capital (primarily housing in the case of the personal sector). The BIS survey of international balance sheet data reported by Kneeshaw (1995) indicates just how poor are these data in many EU countries. It is encouraging that the European Monetary Institution (the forerunner to the European Central Bank) monitored house price movements in its Convergence Report (EMI 1998), but a notable absence was data for Germany which does not compile official, composition-corrected house prices indices of a wide coverage.

In the medium run, the institutional differences we have highlighted for the countries at the extremes would be likely to create severe tensions within EMU, or at least stability problems for these countries. The decision by the UK and Sweden to stay out for the time being perhaps reflects mainly the constraints imposed by their business cycles being sharply out of phase with that of the EMU core, than a clear appreciation of the fundamental institutional difficulties, though the UK Treasury has acknowledged that some exist (HM Treasury, 1997).

What then could countries at the 'liberal property-owning democracy' extreme, such as the UK, Ireland and Finland, do to reduce these problems? Key areas for action are the following:

\section{Encourage the use of fixed-rate mortgages and loans more generally.}

Any switch to fixed rate debt is likely to take some time. However, to hasten such a development, it would be necessary to stimulate a parallel market for fixed-rate personal saving products. It seems likely that quite modest and temporary tax breaks for such savings products could help bring about a major portfolio switch in this direction. Further, a more radical structural change in housing finance towards the provision of long-term fixed rate 
debt could be facilitated by adopting the legal framework necessary to allow UK lenders to issue EU-standard mortgage bonds. By following the EU-standard, mortgage bonds would enjoy various regulatory privileges, not least a more favourable treatment under the Solvency Ratio Directive. According to the EMF, at least seven EU countries, including Finland, have adopted mortgage bond laws, and Ireland is considering following.

\section{2. $\quad$ Place tougher prudential upper limits on loan-to-value ratios.}

A small move in this direction could be rationalized on the grounds of consumer protection to avoid a repetition of the mortgage possession crisis of the early 1990's: in the decade 1988-1998, around half a million UK households lost their homes. A substantial move, however, would be likely to lead to substantial welfare losses by households.

\section{Retain a more significant pay-as-you go element in the public pension system}

As Merton (1987) has argued, retaining a significant pay-as-you-go system can reduce one of the problems of incomplete markets, caused by the fact that human capital is largely uninsurable. It also has the advantage for economies at the more liberal property-owning end of the institutional spectrum of reducing the prospective gap between them and the core Eurozone economies, particularly if the proportion of funded pensions in these economies rises..

4. Encourage the development of the private rented sector and encourage the move towards market rents in as much of the social housing sector as possible.

UK housing economists have long argued for this, see Minford et al (1987), Hughes and McCormick (1987, 1991), Muellbauer (1990), Maclennan (1994) among others. There should be substantial micro- as well as macro-economic benefits. Moreover, a sizeable market rented sector would make feasible a return to the use of imputed rents based on market rents, to measure the housing costs of owner-occupiers in the consumer price index, as in much of the rest of Europe. This would avoid the perverse effect, that a rise in rates drives up the official measure of inflation, almost unique to the UK in Europe. 
5. As a substitute for increasing frictions in the housing market, (e.g by raising Stamp Duty to higher levels seen elsewhere in Europe) which reduce labour mobility, use property taxes more flexibly to reduce house price volatility.

A tax on imputed rent based on current market value, particularly with an exemption for the lowest prices, could have a valuable role as an automatic stabilizer or as a policy instrument. Note that in countries with UK type institutions, house prices tend to rise faster than incomes in the upswing. As Cameron and Muellbauer $(1998,2000)$ argue, the current UK property tax (the Council Tax) is fundamentally defective in a number of dimensions. The tax is far too weakly linked to market values: it retains major elements of the Poll Tax, being highly regressive within local areas, with a zero marginal tax rate for properties valued at over $£ 320 \mathrm{k}$ and $50 \%$ discounts for owners of second or third houses, and highly regressive across regions. Regular revaluations would be a crucial part of the necessary reforms. ${ }^{24}$ In an ideal world, it would be best for such a tax to be set at a uniform national rate and probably to hand responsibility to the Bank of England to set the rate every year: after all, the Bank follows asset prices closely and could apply much of its interest rate setting expertise, which might seem irrelevant after adopting the Euro, to its task to help stabilize the UK economy. Even with all the other reforms mentioned here, the history of UK house price volatility is likely to imply a higher volatility risk than in the core EMU countries for some time to come.

6. Encourage policy makers in those EMU countries at the other end of the institutional spectrum to open credit markets, the legal profession and estate agents to competition, to reduce legal barriers to the use of housing collateral, and to reduce transactions costs.

These reforms would have general benefits for Europe of encouraging labour mobility and bringing other efficiency and welfare gains.

An interesting question is whether our analysis has predictive content in understanding where in the Eurozone tensions have arisen 20 months after our article went to press. According to IMF country reports, OECD economic surveys and the most recent reports of 
the respective central banks or ministries of finance, Eurozone countries where overheating or risks of overheating are causing concern are, in order of seriousness, Ireland, The Netherlands, and Finland. Let us take each in turn.

\section{Ireland}

Inflation in Ireland recently breached the 5\% level. Given Ireland's remarkable growth performance in the last decade, and especially the last five years, higher inflation is not unexpected: pay increases in the sectors where productivity growth is strongest put pressure on pay in the less dynamic sectors, see IMF Staff country report on Ireland for 1999. But it is clear that with house prices rising at around $20 \%$ per annum in 1999, more than doubling the 1995 level of prices, this must present a clear domestic inflation threat. In addition to the mechanisms to which we pointed in Section 2, migration to Ireland, often of return-migrants, has been a major cause of the remarkable supply response of the Irish economy. Pricing potential immigrants out of the housing market is bound to add to wage pressure. Apart from encouraging housebuilding, the policy response has been to raise Stamp Duty in both 1999 and 2000, though now there are concerns about this increasing the entry barrier for first-time buyers, and recently to introduce an 'anti-speculation' tax. Ireland is one of the few countries in the world without a domestic property tax and the authorities have, so far, eschewed this method of dampening demand and inflation.

\section{The Netherlands}

The Dutch central bank is concerned about overheating in the Dutch economy after a decade in which growth has been above the EU average. As we have noted, ownership of equities is relatively high in The Netherlands and the rise in financial asset prices will have contributed to strong demand growth. A report (De Nederlandsche Bank, 2000) shows that between 1994 and 1999 the mortgage debt-to-GDP ratio rose more rapidly in the Netherlands than anywhere else in the EU. Among the causes has been a very substantial liberalisation of credit conditions, especially for two-earner households, where the income of the second earner is now weighted as a lending criterion much more heavily than in the past. The tax regime continues to give substantial tax relief on mortgage interest payments. House prices have risen strongly in recent years. Perhaps as a result of strong demand, the land-use

planning system has not been able to respond as flexibly as in the past. Concerns expressed 
about consumers using cheap mortgage loans to fund other spending ('equity withdrawal') and about households, financial institutions and the economy as a whole becoming more vulnerable to a downturn will be familiar to many British readers. There is now an active debate in the Netherlands about the merits of limiting tax relief and tightening the regime of bank regulation for mortgage lending.

\section{Finland}

The improvement in growth in Finland is of more recent vintage than in The Netherlands. Though the unemployment rate is still over 9\%, inflationary pressures are emerging. House prices are rising at around $20 \%$ per annum and wage settlements above the Eurozone average are causing concerns both to the Ministry of Finance and to the IMF mission. The latter is also concerned about the housing market constraining the movement of workers to locations where labour demand is growing most strongly, see discussion in Section 2.5 above of similar UK experience, and suggests various measures to boost the supply of rental housing.

In our view this thumbnail sketch demonstrates the predictive content and the relevance of our analysis of assumptions in monetary policy transmission and of the range of policy options through which domestic policy makers can reduce the risks that come from the 'one size fits all' interest rate policy.

We conclude by examining entry prospects for the UK. Being outside the Eurozone has enabled the Bank of England to raise interest rates to compensate for the demand pressures coming from strong asset prices and the technology boom which has been heavily focused on the service sector, both areas where the UK is more sensitive than the Eurozone. Some support has come from fiscal measures, in particular the now completed phasing out of mortgage interest tax relief and successive rise in Stamp Duty on housing transactions. However, tighter monetary policy as the main response, has added further to the overvaluation of Sterling against the weak Euro, given the strength of the US Dollar. The sectors most vulnerable to European competition, manufacturing, agriculture and tourism have therefore borne the brunt of the slowdown and this has been reflected in widening regional inequalities in employment and unemployment rates, incomes and house prices. With hindsight, it is likely, inter alia from the strength of the housing market and the decline in the personal sector saving ratio, that had the UK been a founder member of the Eurozone it 
would by now have been second only to Ireland in overheating, in the absence of other policy responses.

In terms of the five economic tests (HM Treasury, October 1997) for Euro entry, the UK looks little closer to entry than in 1997. The exchange rate is further away from a feasible entry rate, though short interest rate differentials have halved since October 1997, Eurozone growth is overtaking UK growth and long-term government bond yields are now lower in the UK than in Germany. But the sustainable convergence, which is the first of the Chancellor's economic tests, remains elusive on current policies. Indeed, the higher Stamp Duty rates, which reduce differentials in housing transactions costs with the Eurozone, threaten the second of the economic tests by making the labour market less flexible. There has been only a marginal rise in the proportion of housing tenures in the market rented sector, still the lowest in the EU. The cult of equity investment and pension reform have made some progress in the Eurozone, but the UK-Eurozone gap is still very large. Though the mortgage market in The Netherlands appears to have gone through an important liberalisation, the barriers to similar developments in Germany, France and, above all, Italy remain high. Without policy reform of the types discussed above, entry still looks too risky even if the exchange rate were to move into a feasible region. 


\section{REFERENCES}

Bank for International Settlements (BIS), (1995), Financial Structure and the Monetary Policy Transmission Mechanism, Basle.

Barran, F, Coudert and B Mojon, (1997), "La transmission des politiques monétaires dans le pays européens', Revue Française d'Economie.

Barrell, R, A Gurney and J In'tVeld (1991), “The Introduction of Wealth into a Model of the World Economy", National Institute of Economic and Social Research.

Barro, R, (1974), “Are Government Bonds Net Wealth?”, Journal of Political Economy, 82, 10951118 .

Bernanke, B and A S Blinder, (1992), "The Federal Funds Rate and the Channels of Monetary Transmission", Journal of Economic Perspective, 9, 4, 27-48.

Bernanke, B and M Gertler, (1995), "Inside the Black Box: the Credit Channel of Monetary Policy Transmission", Journal of Economic Perspectives, vol 9, no 4.

Bernanke, B, M Gertler, and M Watson (1997), "Systematic Monetary Policy and the Effects of Oil Price Shocks", Brookings Papers on Economic Activity, no. 1, 91-142.

Blackaby, D H and D N Manning, (1992), "Regional Earnings and Unemployment - a Simultaneous Approach", Oxford Bulletin of Economics and Statistics, vol 54, no 4, 481-502.

Bond, S and T Jenkinson, (1996), "The Assessment: Investment Performance and Policy", OXREP, Summer 1996, pp.1-29.

Borio, C E V, (1997). "Credit Characteristics and the Monetary Policy Transmission Mechanism in Fourteen Industrial Countries", in K Alders (eds), Monetary Policy in a Converging Europe, Kluwer, Amsterdam.

Bover, O, J Muellbauer and A Murphy, (1989), "Housing, Wages and UK Labor Markets, Oxford Bulletin of Economics and Statistics, 51, 2, March, pp.97-136.

Britton E and J Whitley, (1997), "Comparing the Monetary Transmission Mechanism in France, Germany, and the United Kingdom: some Issues and Results”, Bank of England Quarterly Bulletin.

Cameron, G and J Muellbauer (1998), "The Housing Market and Regional Commuting and Migration Choices", Scottish Journal of Political Economy, vol 45, no 4, 420-446.

Cameron, G and J.Muellbauer (2000), "Five Key Council Tax Reforms and Twelve Reasons to Enact Them", New Economy 7, 88-91.

CECODHAS (1995), European Social Housing, Paris: CECODHAS. 
Church K, P Smith and K Wallis (1994), “Econometric Evaluation of Consumers' Expenditure Equations", Oxford Review of Economic Policy, 10, 71-85.

Cochrane, J H, (1994), "Comment on" "What Ends Recessions?" by C Romer and D Romer, in NBER Macroeconomics Annual 1994, MIT Press.

Deaton, A S, (1992), Understanding Consumption, Oxford: Oxford University Press.

De Grauwe, P (1995), The Economics of Monetary Union, Oxford: Oxford University Press.

De Nederlandsche Bank NV (2000), “A Closer Look at Bank Mortgage Operations”, External Relations and Information Dept., Jan. $19^{\text {th }}$.

Department of the Environment and Local Government (1998), Action on House Prices, Dublin: DOELG.

Diamond, D B and M J Lea, (1992), "Housing Finance in Developed Countries", Journal of Housing Research, vol 3, no 1, (special issue).

Dornbusch, R, C Favero and F Giavazzi, (1998), "Immediate Challenges for the European Central Bank", Economic Policy, April 1998, 17-62 (with discussion).

Economist (1992), "House Prices", December 26", $95-97$.

Eichengreen, B, (1994), International Monetary Arrangements for the $21^{\text {st }}$ Century, Washington DC: The Brookings Institute.

European Community Mortgage Federation (1987-1990), Annual Reports.

European Monetary Institute (1998), Convergence Report, report required by Article 109j of the Treaty establishing the European Community, Frankfurt am Main: EMI.

European Mortgage Federation, (1998), Annual Report 1997, Brussels: EMF, similarly for earlier years.

European Network of Housing Economists (ENHR), Housing Finance Working Party (1995).

Eurostat, (1996), Demographic Statistics, Luxembourg: OOPEC.

Eurostat, (1997), Regional Year Book 1997, Luxembourg: OOPEC.

Evans, M K, (1969), Macroeconomic Activity: Theory, Forecasting and Control; an Econometric Approach, New York: Harper and Row. 
Friedman, B and K Kuttner (1992), “Money, Income, Prices and Interest Rates”, American Economic Review, 82, 472-492.

Funke, N and M Kennedy, (1997), "International Implications of European Economic and Monetary Union”, OECD Economics Department Working Paper, no 174.

Gerlach, S and F Smets, (1995), "The Monetary Transmission Mechanism: Evidence from the G-7 Countries”, BIS Discussion Paper.

Guiso, L, T Jappelli and D Terlizzese (1992), "Saving and Capital Market Imperfections: The Italian Experience", in E Koskela and J Paunio (eds), Savings Behavior: Theory, International Evidence and Policy Implications, Scandinavian Journal of Economics series, Cambridge and Oxford: Blackwells, pp. 43-59.

Haffner, M (1998), Housing Statistics in the European Union, Brussels: DGV.

Hamann, A J, (1997), “The Reform of the Pension System in Italy”, IMF Working Paper, WP/97/18, European Department.

Hedman, E (ED), Housing in Sweden in an International Perspective, Kalskrona: BOVERKET.

Hendry, D F, (1984), "Econometric Modelling of House Prices in the UK", in Econometrics and Quantitative Economics (ed), D F Hendry and K F Wallis, Oxford: Basil Blackwell.

Hendry, D F, (1985), "Monetary Economic Myth and Econometric Reality”, Oxford Review of Economic Policy, vol 1, no 1, 72-84

Hills, J (1998) Housing, Tenure and International Comparisons of Income Distribution in Kleinman, M, Matznetter, W and Stephens, M (eds.) European Integration and Housing Policy, London: Routledge.

HM Treasury, (1997), "UK Membership of the Single Currency: An Assessment of the Five Economic Tests", London: HM Treasury.

Hughes, G and B McCormick, (1987), "Housing Markets, Unemployment and Labour Market Flexibility in the UK", European Economic Review, 31, 3, April, pp.615-41.

Hughes, G and B McCormick, (1991), "Housing Markets, Unemployment and Labour Market Flexibility in the UK", in G de Menil and R J Gordon (eds), International Volatility and Economic Growth: The First Ten Years of the International Seminar on Macroeconomics, Amsterdam, London and Tokyo, Elsevier Science: New York, pp.83-109.

IMF, Staff Country Report no. 99/108: Ireland.

Jackman, R and S Savouri, (1992b), "Regional Migration in Britain: an Analysis of Gross Flows Using NHS Central Register Data”, Economic Journal, 102, 415, November, pp.1433-50. 
Kennedy, N O (1996), "The Impact of Economic Convergence of Housing and Mortgage Markets in the EU", Council of Mortgage Lenders European Morgage Review, March, 22-41

Kennedy, N and P Anderson, (1994), "Household Saving and Real House Prices: an International Perspective", Bank for International Settlements Working Paper 20.

Kneeshaw, J T, (1995), “A Survey of Non-Financial Sector Balance Sheets in Industrialized Countries: Implications for the Monetary Policy Transmission Mechanism”, Bank for International Settlements, Working Paper 25.

Kopits, G, (1997), “Are Europe's Social Security Finances Compatible with EMU?”, IMF Fiscal Affairs Department Working Paper, February.

Kosonen, K (1993), "Housing Finance in Finland: Institutional Features and Recent Developments" in Turner, B and Whitehead C (eds), Housing Finance in the 1990s, Research Report SB:56, Gavle: National Swedish Institute for Building Research.

Kosonen, K and P Timonen, (1994), "Household Debt Problems in a Bank-Dominated Housing Finance System: the Case of Finland", paper presented at the European Network for Housing Research Conference: Making the Connections, University of Glasgow, August/September.

Krugman, (1992), Geography and Trade, Leuven: Leuven University Press and MIT Press.

Lea, M J, R Welter and A Dübel, (1997), "Study on Mortgage Credit in the European Economic Area", European Commission, Directorate General XXIV and Empirica.

Leal, J, (1992), Informe para una Nueva Política de Vivienda, Madrid: Ministerio de Obras Públicas Transportes.

Lucas, R E, (1976), "Econometric Policy Evaluation: a Critique”, in Brunner K and A H Meltzer, (eds), The Phillips Curve and Labour Markets, North-Holland, Amsterdam.

Lujanen, M, (1998), "Comparing Subsidy Policies in Four Nordic Countries", paper presented at European Network for Housing Research Conference, Renewal, Sustainability and Innovation, Cardiff, September.

Maclennan, D, (1994), A Competitive UK Economy: Issues for Housing Policies, York: Joseph Rowntree Foundation.

Maclennan, D, M Stephens and P A Kemp, (1997), "Housing Policy in the EU Member States", Social Affairs Series, WP-14, European Parliament, Luxembourg.

McCauley, R N and W R White, (1997), "The Euro and European Financial Markets", in P Masson, T Krueger and B Turtleboom (eds), EMU and the International Monetary System, IMF, Washington, DC. 
McCrone, G and Stephens, M, (1995), Housing Policy in Britain and Europe, London: UCL Press.

Meen, G, (1993), "The Treatment of House Prices in Macroeconometric Models: a Comparison Exercise", DOE Occasional Paper, Housing and Urban Monitoring and Analysis.

Meen, G (1996), "Ten Propositions in Housing Macroeconomics: an Overview of the 1980s and the Early 1990s”, Urban Studies, vol 33, no 3, 425-444.

Merton, R, (1987), "On the Role of Social Security as a Means for Efficient Risk Sharing in an Economy where Human Capita is not Tradable", in Issues in Pension Economics, edited by Z Bodie, J Shoven and D Wise, Chicago University Press.

Miles, D, (1994), Housing, Financial Markets and the Wider Economy, New York: Wiley.

Miles, D, (1998), “The Implications of Switching from Unfunded to Funded Pension Systems", National Institute Economic Review, 1, 71-86.

Minford, P M Peel and P Ashton, (1987), The Housing Morass, London: Institute of Economic Affairs.

Muellbauer, J, (1990), “The Great British Housing Disaster and Economic Policy”, IPPR Economic Study No 5, London.

Muellbauer, J, (1992), “Anglo-German Differences in Housing Market Dynamics: the Role of Institutions and Macro Economic Policy", European Economic Review, 36, Papers and Proceedings, pp.539-48.

Muellbauer, J, (1996), "Income Persistence and Macropolicy Feedbacks in the US", Oxford Bulletin of Economics and Statistics, 58, pp.703-733.

Muellbauer, J and R Lattimore, (1995), "The Consumption Function: A Theoretical and Empirical Overview", in Handbook of Applied Econometrics, (ed) M H Pesaran and M Wickens, Blackwells.

Muellbauer, J and A Murphy, (1991), "Regional Economic Disparities: the Role of Housing", in A Bowen (ed), Reducing Regional Inequalities, London: National Economic Development Office.

Muellbauer, J and A Murphy, (1995), "Explaining Regional Consumption in the UK”, presented at the IFS/Bank of Portugal conference on the Microeconomics of Saving, Lisbon, 1995.

Muellbauer, J and A Murphy, (1997), "Booms and Busts in the UK Housing Market" Economic Journal, vol 107, 1701-1727. 
Papa, O, (1992), Housing Systems in Europe: Part II. A Comparative Study of Housing Finance, Delft: Delft University Press.

Prati A and G J Schinasi, (1997), "EMU and International Capital Markets: Implications and Risks", in P Masson, T Krueger and B Turletboom (eds), EMU and the International Monetary System, IMF, Washington DC.

Roseveare D, W Leibfritz , D Fore and E Wurzel, (1996), “Ageing Populations, Pension Systems and Government Budgets: Simulations for 20 OECD Countries”, Economics Department Working Paper No 168, OECD Paris.

Rottemberg, J J and M Woodford (1997), “An Optimization Based Econometric Framework for the Evaluation of Monetary Policy”, NBER Macroeconomics Annual, Cambridge, Mass: MIT Press.

Schiantarelli, F, (1996), "Financial Constraints and Investment: Methodological Issues and International Evidence", OXREP, Summer, pp.70-89.

Sims, C A, (1980), “Macroeconomics and Reality”, Econometrica, vol 48, pp. 1-48.

Sims, C A, (1992), "Interpreting the Macroeconomic Time Series Fact: the Effects of Monetary Policy”, European Economic Review, Vol 36, pp.975-1000.

Sims, C A, (1996), "Macroeconomics and Methodology", Journal of Economic Perspective, 10, 10520.

Spencer, P (1999), "UK Housing and Mortgage Markets: Have Serious an Obstacle to EMU", Housing Finance, 41, 25-32.

Stephens, M, (1995), "Monetary Policy and House Price Volatility in Western Europe", Housing Studies, 10, 551-564.

Stephens, M. (2000) 'Convergence in European mortgage systems before and after EMU', Journal of Housing and the Built Environment, 15(1), pp. 29-52

Taylor, J B, (1993), "Discretion Versus Policy Rules in Practice”, Carnegie-Rochester Series on Public Policy.

Taylor, J B (1995), “The Monetary transmission Mechanism: an Empirical Framework", Journal of Economic Perspectives, 9, 11-26.

Todd, R M, (1990), "Vector Autoregression Evidence in Monetarism: Another Look at the Robustness Debate", Federal Reserve Bank of Minneapolis Quarterly Review, Spring, pp.1937. 
White, W R, (1998), “The Coming Transformation in Continental European Banking”, Bank for International Settlements Discussion Paper 54.

Woolwich Building Society, (1993), Survey, January. 


\section{APPENDIX 1}

With a C.E.S. utility function in the two period case, the solved-out consumption function is as follows:

$$
\mathrm{c}_{1}=\left[\mathrm{A}_{0}\left(1+\mathrm{r}_{0}\right)+\mathrm{y}_{1}+\mathrm{y}_{2}^{\mathrm{e}} / 1+\mathrm{r}_{1}^{\mathrm{e}}\right] / \mathrm{k}
$$

where $\mathrm{k} \approx 1+1 /\left[1+\sigma \delta+(1-\sigma) \mathrm{r}_{1}^{\mathrm{e}}\right]$

and $\mathrm{c}_{1}=$ current real consumption, $\mathrm{A}_{0}=$ initial real assets, $\mathrm{y}_{1}=$ current real non-property income, $\mathrm{y}_{2}^{\mathrm{e}}=$ expected .... income, $\mathrm{r}_{\mathrm{t}}=$ real interest rate linking period $\mathrm{t}$ and $\mathrm{t}+1, \sigma=$ elasticity of intertemporal substitution, $\delta=$ subjective discount rate.

One expects $0<\sigma<1$.

$\partial \mathrm{c}_{1} / \partial \mathrm{r}_{1}^{\mathrm{e}}$ CAN be positive e.g. if $\sigma$ close to zero, $\mathrm{y}_{2}^{\mathrm{e}}=\mathrm{y}_{1}$ and $\mathrm{A}_{0} / \mathrm{y}_{1}$ is large.

In the $\mathrm{UK}, \partial \mathrm{c}_{1} / \partial \mathrm{r}_{1}^{\mathrm{e}}$ appears to be negative, suggesting $\sigma$ bigger than zero.

But the effect appears to be small relative to the indirect effects via asset prices. 


\section{APPENDIX 2}

EFFECTS OF PERMANENT RISE IN REAL HOUSE PRICE ON CONSUMPTION IN A SIMPLE LIFE-CYCLE MODEL

Assume fixed relative prices for $t=1, \ldots, \mathrm{T}$ of non-housing consumption and housing. Then the $2 \mathrm{~T}$ dimensional optimization intertemporal problem reduces to a two-good problem (by the Hicks aggregation theorem) with the budget constraint:

$$
\mathrm{c}+\mathrm{ph}=\mathrm{rW} / 1+\mathrm{r}
$$

where $\mathrm{c}=$ non-housing consumption, $\mathrm{p}=$ relative price of housing, $\mathrm{h}=$ quantity of housing services, $\mathrm{r}=$ real interest rate, $\mathrm{W}=$ life-cycle wealth including housing wealth.

Total differentiation with $\mathrm{r}$ fixed gives

$$
d c+(d p) h+p(d h)=(r / 1+r) d W
$$

where $\mathrm{dW}=(\mathrm{dp}) \mathrm{H}$, and $\mathrm{H}$ is the stock of housing.

Thus $\partial \mathrm{c} / \partial \mathrm{p}=(\mathrm{r} / 1+\mathrm{r}) \mathrm{H}-\mathrm{h}-\mathrm{p} \partial \mathrm{h} / \partial \mathrm{p}$

$$
\begin{aligned}
& =(\mathrm{r} / 1+\mathrm{r}) \mathrm{H}-\mathrm{h}(1+\mathrm{e}) \\
& =\text { wealth effect minus income and substitution effect. }
\end{aligned}
$$

Here $\mathrm{e}=$ own-price elasticity of demand for housing $(\mathrm{e} \approx-0.5$ to -0.7$)$ 